\title{
Water Quality of Selected Wetland Streams in Central and Eastern Massachusetts,1988-89
}

U.S. Geological Survey

Water-Resources Investigations Report 95-4157

Prepared in cooperation with the MASSACHUSETTS DEPARTMENT OF ENVIRONMENTAL PROTECTION, OFFICE OF WATERSHED MANAGEMENT

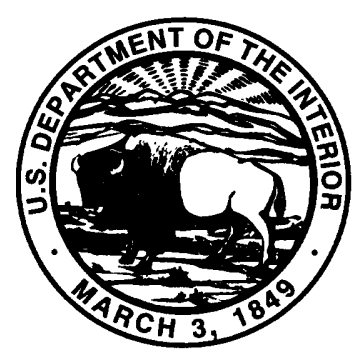




\section{Water Quality of Selected Wetland Streams in Central and Eastern Massachusetts,1988-89}

\section{By DAVID S. ARMSTRONG and ROBERT M. LENT}

U.S. Geological Survey

Water-Resources Investigations Report 95-4157

Prepared in cooperation with the

MASSACHUSETTS DEPARTMENT OF ENVIRONMENTAL

PROTECTION, OFFICE OF WATERSHED MANAGEMENT



Marlborough, Massachusetts 


\title{
U.S. DEPARTMENT OF THE INTERIOR BRUCE BABBITT, Secretary
}

\author{
U.S. GEOLOGICAL SURVEY \\ Gordon P. Eaton, Director
}

For additional information write to:

Copies of this report can be purchased from:

Chief, Massachusetts-Rhode Island District

U.S. Geological Survey

U.S. Geological Survey

Earth Science Information Center

Water Resources Division

Open-File Reports Section

28 Lord Road, Suite 280

Box 25286, MS 517

Marlborough, MA 01752

Denver Federal Center

Denver, CO 80225 


\section{CONTENTS}

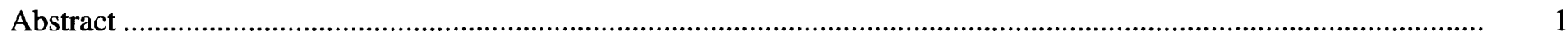

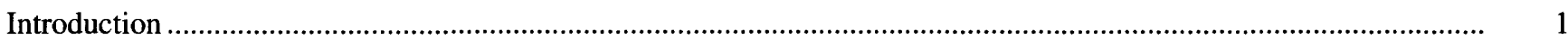

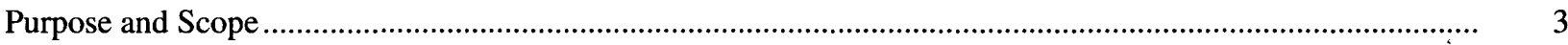

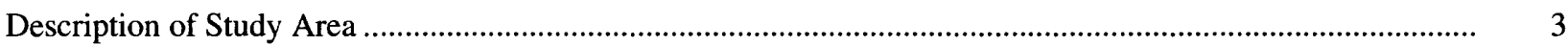

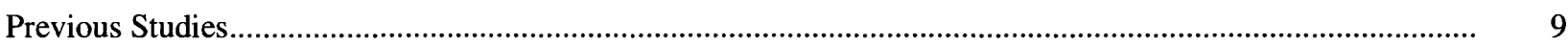

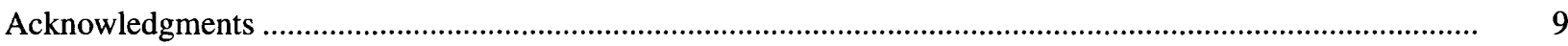

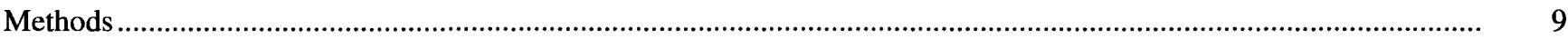

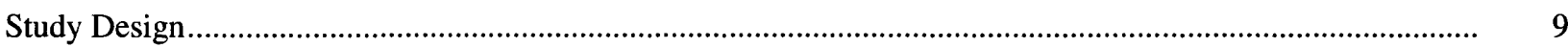

Measurement of Basin, Stream, and Wetland Characteristics ........................................................... 10

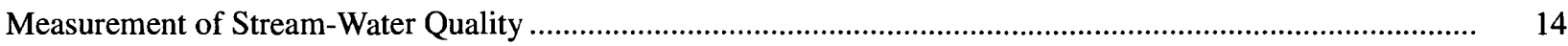

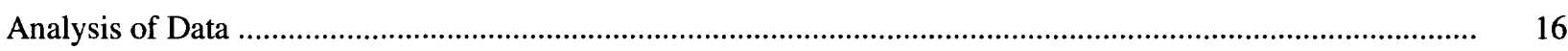

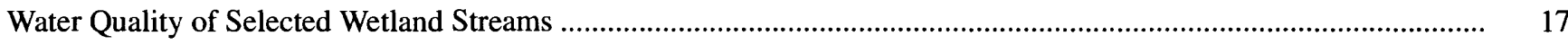

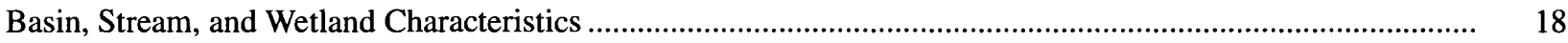

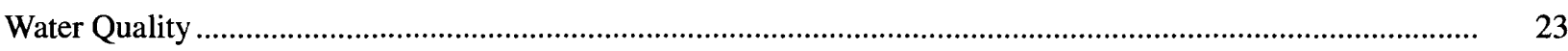

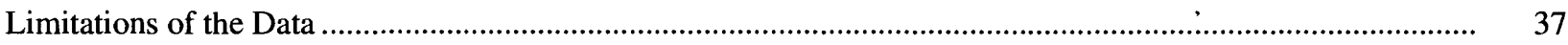

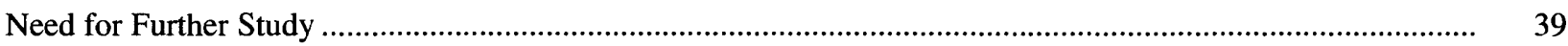

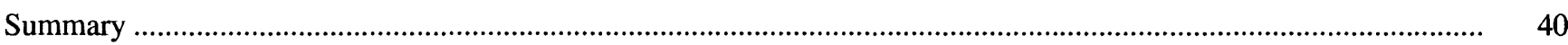

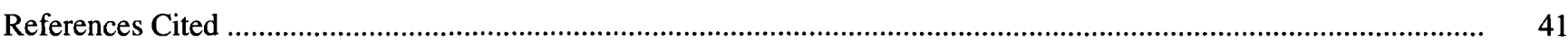

\section{FIGURES}

1. Map showing location of selected areas in Massachusetts where wetland streams were studied..........................

2-5. Maps showing location of hydrologic data-collection sites and contributing drainage-basin divides in:

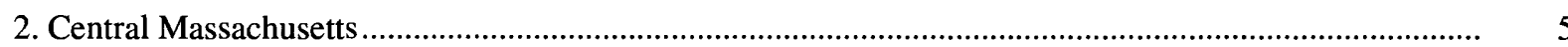

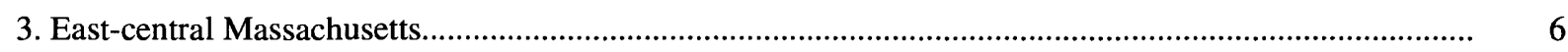

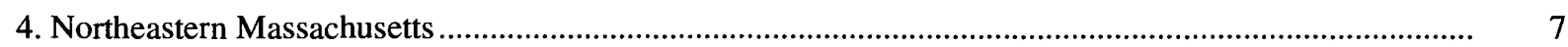

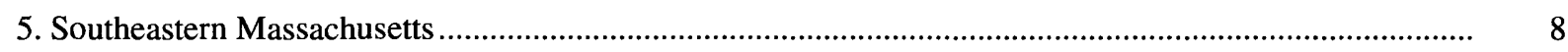

6. Schematic diagrams of wetland reaches that were not selected for this investigation..........................................

7. Map showing wetland reaches dominated by palustrine forested wetlands and palustrine scrub-shrub and emergent wetlands, central and eastern Massachusetts.

8. Trilinear diagram showing composition of water from selected wetland streams, central and eastern Massachusetts, 1988-89

9-11. Graphs showing:

9. Percentage of saturation of dissolved oxygen for selected sampling sites, central and eastern Massachusetts, 1988-89

10. Effects of wetland reaches on stream-water quality for selected properties and constituents, central and eastern Massachusetts, 1988-89

11. Effects of wetland characteristics on the water quality of selected wetland streams, central and eastern Massachusetts, 1988-89 


\section{TABLES}

1. Information for selected wetland-stream sampling sites in central and eastern Massachusetts

2. Comparison of quality-assurance data for MDEP and USGS samples collected from Robinson Brook,

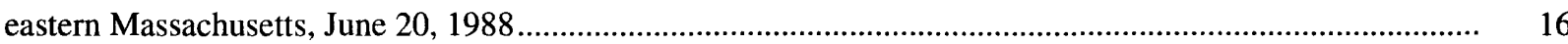

3. Group criteria for basin, stream, and wetland characteristics ........................................................................ 17

4. Basin and stream characteristics and wetland classification for selected wetland streams, central and eastern Massachusetts, 1988-89

5. Summary of water-quality data from selected wetland streams, central and eastern Massachusetts, 1988-89

6. Relative changes in water quality throughout primary wetland-stream reaches, central and eastern

Massachusetts, 1988-89.

7. Relative changes in water quality throughout subordinate wetland-stream reaches, central and eastern

Massachusetts, 1973-81

\section{CONVERSION FACTORS AND WATER-QUALITY INFORMATION}

\section{Conversion Factors}

\begin{tabular}{rll}
\hline Multiply & By & To obtain \\
\hline centimeter $(\mathrm{cm})$ & 0.3937 & inch \\
cubic meter $\left(\mathrm{m}^{3}\right)$ & 264.2 & gallon \\
cubic meter per second $\left(\mathrm{m}^{3} / \mathrm{s}\right)$ & 35.3145 & cubic foot per second \\
gram $(\mathrm{g})$ & 0.03527 & ounce, avoirdupois \\
$\operatorname{gram}(\mathrm{g})$ & 0.002205 & pound, avoirdupois \\
kilometer $(\mathrm{km})$ & 0.6214 & mile \\
$\operatorname{meter}(\mathrm{m})$ & 3.281 & foot \\
square kilometer $\left(\mathrm{km}^{2}\right)$ & 0.3861 & square mile
\end{tabular}

For temperature conversions between degrees Celsius $\left({ }^{\circ} \mathrm{C}\right)$ and degrees Fahrenheit $\left({ }^{\circ} \mathrm{F}\right)$, the following formulas may be used:

$$
\begin{aligned}
{ }^{\circ} \mathrm{C} & =5 / 9 \times\left({ }^{\circ} \mathrm{F}-32\right), \\
{ }^{\circ} \mathrm{F} & =\left(1.8 \times{ }^{\circ} \mathrm{C}\right)+32 .
\end{aligned}
$$

\section{Water-Quality Information}

Chemical concentration in water is expressed in milligrams per liter (mg/L) or micrograms per liter $(\mu \mathrm{g} / \mathrm{L})$. Milligrams and micrograms per liter are units expressing the weight of the solute per unit volume (liter) of water. One thousand micrograms per liter is equivalent to 1 milligram per liter. Milligrams per liter is approximately equivalent to parts per million. Micrograms per liter is approximately equivalent to parts per billion. 


\title{
Water Quality of Selected Wetland Streams in Central and Eastern Massachusetts, 1988-89
}

\author{
By David S. Armstrong and Robert M. Lent
}

\section{Abstract}

Water quality, and basin, stream, and wetland characteristics are described for selected wetland streams of central and eastern Massachusetts. Water-quality data from 22 wetland reaches on 15 streams were analyzed using boxplots for selected water-quality and basin, stream, and wetland characteristics. Nonparametric statistical techniques were used to check for significant differences between upstream and downstream concentrations and loads. Stream nutrient and dissolved-oxygen conditions varied in the selected wetland-stream reaches. For the 22 wetland stream reaches, properties and constituents that increased in more than 65 percent of the stream reaches included discharge, specific conductance, temperature, turbidity, sodium, dissolved and total ammonia plus organic nitrogen, and iron. Easily measured characteristics of wetland streams were not reliable indicators of water quality for the existing data set. The lack of consistent changes in water quality between the upstream and downstream sampling sites suggests that the existing data for the selected wetland reaches cannot be used to reliably determine the effect of wetlands on stream-water quality.

A carefully designed data-collection program is needed for the successful evaluation of dissolved oxygen and nutrients in wetland reaches. Components of a data-collection program would include careful site selection, proper timing and intensity of sampling throughout the year, and additional water-quality data needed for dissolved-oxygen and nutrient modeling.

\section{INTRODUCTION}

Numerous studies have investigated the water quality of streams and isolated wetlands, but relatively few studies have investigated the water quality of wetland streams in detail (Mulholland and Kuenzler, 1979; Mulholland, 1981; Peverly, 1982, 1985; Elder, 1985; Hampson, 1989; Meyer and Edwards, 1990; Suurballe, 1992). The effect of wetlands on hydrology and water quality is thought to be dependent on the location of wetlands in the landscape (Brinson, 1988; Hemond and Benoit, 1988; O’Brien, 1988; Winter, 1988; Johnston and others, 1990). Whigham and others (1988) hypothesized that the effect of riparian wetlands on streamwater quality is directly related to the percentage of total river flow that contacts the wetland environment and that, as stream order increases, the percentage of total flow that contacts wetlands decreases. They also determined that riparian wetlands have little effect on stream-water quality during nonflooding periods and that most nutrient processing occurs directly within the stream ecosystem.

Wetlands modify or alter many characteristics of streams, including river slope, channel width, depth, flow velocity, discharge, sediment type, temperature, and nutrient and light regimes. Upland streams tend to have mineral substrates, relatively confined channels, moderate gradients, clear water, moderate to high velocities, and turbulent flow. In contrast, most wetland streams have organic and (or) fine-grained mineral substrates, poorly defined channels, low gradients, humiccolored water, low velocities, and less turbulent flow. In addition, reduced oxygen conditions are much more common in wetland soils than in upland soils. These reduced conditions can have a marked effect on several biochemical transformations unique to anaerobic conditions (Mitsch and Gosselink, 1986). Mulholland and Kuenzler (1979) and Mulholland (1981) indicated that 
wetland streams may be less efficient than upland streams in processing allochthonous (introduced) organic materials. Mulholland (1981) contrasted a forested wetland stream in the coastal plain of North Carolina to two upland streams in New England and determined that the wetland stream retained a much larger proportion of its particulate organic-carbon material and had a higher loading rate of dissolved organic carbon (DOC) than the two upland streams. The retention of organic material was attributed to physical and hydrologic characteristics that are typical of wetland streams. These characteristics include low gradients and dense vegetation that produce low water velocities with very little erosive force, poorly defined channels, complex flowpaths, numerous debris dams, and large flood plains. The presence of abundant organic material, reduced oxygen conditions, and low velocities, which increase the contact time that water has with organic material in a stream, likely accounts for most differences in water quality between upland and wetland streams.

Few studies have specifically investigated low dissolved-oxygen (DO) concentrations in wetland streams. Hampson (1989) investigated humic-colored streams flowing through forested wetlands in Florida and determined that changes in water temperatures and the discharge of natural oxygen-demanding substances were the primary factors affecting DO concentration. Hampson (1989) also determined that photosynthesis generally was not a major contributor of DO except during periods of low flow. Beck and others (1974) studied the organic and inorganic geochemistry of wetland rivers on the coastal plain of the southeastern United States and determined that the percentage of oxygen saturation decreases with increasing concentration of organic matter in river water. This was particularly noticeable after large volumes of organic-rich water were flushed from swamps into receiving rivers following intense rains. Beck and others (1974) also determined that low $\mathrm{pH}$ values and relatively high concentrations of aluminum and iron result from high concentrations of organic matter. Edwards (1968) and Thyssen and others (1987) reported that macrophyte growth can slow water velocities and increase water depth, resulting in decreased reaeration and net oxygen consumption. Ferrous (reduced) iron, derived from weathering of minerals or photoreduction of ferric iron also may affect the oxygen balance of some wetland streams (Hynes, 1974). Photochemical oxidation of iron may be responsible for the observed oxygen deficiency in some humic-colored surface water (Miles and Brezonik, 1981). Photoreduction of iron and oxidation of iron by microorganisms have been demonstrated in wetland streams in the New Jersey Pine Barrens (Madson and others, 1986).

Wetlands can have a wide variety of effects on nutrients, transforming some from inorganic to organic forms and acting as a sink or a source for others depending on the element in question, the seasonal loading level, the season of the year, and whether or not the system is aggrading nutrients (Richardson, 1989). In a study of a river-wetland system in northern Florida, Elder $(1985,1988)$ determined that a river-wetland system acted more as a transformer than as a source or sink for nutrients. The river-wetland system assimilated dissolved inorganic nutrients, such as orthophosphate, ammonia, nitrite, and nitrate, that were bioavailable, and released and transported particulate organic forms out of the system. Stream nutrient concentrations typically show seasonal changes in response to biotic activity. Concentrations decrease markedly during periods of plant growth and increase during periods of vegetation dormancy (Likens and others, 1977). Because nutrients are held in vegetation, the concentration of nutrients in the water column is not necessarily indicative of the presence or availability of nutrients in the stream system. Rapid biotic uptake of nutrients such as phosphorus may mean that high concentrations of dissolved phosphorus are rarely detected in streams. Peverly (1982) investigated the accumulation and release of nutrients in a wetland stream in western New York and determined that net annual differences in nitrogen and phosphorus movements may depend on the quantity and timing of water movement and that wetlands may retain little or none of the nutrients carried into them by flowing water. In a subsequent study, Peverly (1985) determined that submersed aquatic plants accumulated nutrients during the growing season, but that senescence and decomposition of these plants contributed substantially to nutrient loads in wetland streams in late summer and autumn when discharge and nutrient loads were small. Elder (1988) determined that wetlands can have diverse effects on constituent transport and that these effects depend on numerous hydrological, chemical, and biological processes. He concluded that the processes that affect water quality in one wetland are not necessarily predictive of processes in another, even if the two wetlands have similar characteristics. 
Wetlands also may have a cumulative effect on stream-water quality and quantity. Johnston and others (1990) investigated the effect of wetlands on water quality. Wetlands were determined to be most effective in removing ammonia, total phosphorus, and suspended solids during high flows and nitrate during low flows. Proximity of wetlands to the stream channel and wetland extent were related to seasonal export of organic nitrogen, orthophosphate, and organic matter. Johnston and others (1990) concluded that the degree to which wetlands alter water quality depends on wetland position in the landscape and that all wetlands in a drainage basin are not similar with regard to their effects on water quality.

The Massachusetts Department of Environmental Protection (MDEP) has monitored water quality for the past 30 years at more than 3,000 surface-water sites in Massachusetts (Massachusetts Department of Environmental Protection, 1992). Analysis of these waterquality data indicate that State water-quality standards are not met in some streams in central and eastern Massachusetts that flow through wetlands (wetland streams) because of undersaturated DO and (or) high nutrient concentrations. These conditions may occur naturally and are most common during periods of low flow and high temperatures in late summer. The need for an improved understanding of water-quality conditions in wetlands prompted the MDEP to participate with the U.S. Geological Survey (USGS) in a cooperative investigation of the water quality of wetland streams in central and eastern Massachusetts.

\section{Purpose and Scope}

The purposes of this report are to (1) describe the basin, stream, and wetland characteristics of selected reaches of wetland streams in central and eastern Massachusetts (fig. 1); (2) describe the concentrations of dissolved oxygen, nutrients, and other water-quality constituents in the selected streams; (3) describe limitations of the data for determining relations among basin, stream, and wetland characteristics and water quality of wetland streams; and (4) identify additional data and information needed to understand processes that affect the water quality of wetland streams.

The physical, hydrologic, biologic, and waterquality data used in this investigation are those reported in Socolow (1994). These data were collected by the MDEP from 1962 through 1988 and by the USGS from
1988 through 1989 at 96 upstream and downstream sampling sites on 72 stream reaches in central and eastern Massachusetts. These data were screened for this investigation to restrict the data set to natural systemsstream reaches where water quality was not obviously affected by point-source discharges, such as those from sewage-treatment plants. Reaches that received discharges from major tributaries that were not sampled were not used in this study. Data from 22 wetland reaches on 15 streams in central and eastern Massachusetts were selected for analysis (figs. 2-5).

\section{Description of Study Areas}

The 22 wetland reaches that were selected for analysis in this investigation represent most major river basins in central and eastern Massachusetts. Drainagebasin divides for these streams, and hydrologic and water-quality data-collection sites are shown in figures 2-5 (Socolow, 1994).

The study areas are characterized by plains and low hills, and topographic relief generally decreases from west to east. The underlying bedrock in central and eastern Massachusetts is predominantly metamorphic and crystalline rock. Bedrock in the study areas is overlain by a veneer of glacial deposits that consist of stratified drift (sand and gravel), lake bottom and marine deposits (clay, silt, and fine sand), or glacial till (an unstratified mixture of clay, silt, sand, gravel, and boulders). Glacial till mantles most uplands and also underlies stratified drift in many stream valleys, whereas stratified drift and (or) glacial-lake deposits occur in most valleys in central and eastern Massachusetts.

Climate in the study areas is classified as temperate. Precipitation and runoff for central and eastern Massachusetts average about 61 and $114 \mathrm{~cm}$, respectively (Gadoury and Wandle, 1986). Precipitation generally is distributed evenly throughout the year, although year-to-year variations may be large (Trombley, 1991). Runoff is highest in March and April, especially when runoff from snowmelt is supplemented by storm runoff. Low flows occur in July, August, and September because of increased evapotranspiration and depletion of soil moisture (Gadoury and Wandle, 1986). There is a transition in vegetation in the study area from northern hardwoods in central Massachusetts to oakhickory in eastern Massachusetts (Jorgensen, 1977). Land use in the study area is variable and includes urban, suburban, agricultural, and forested areas. 


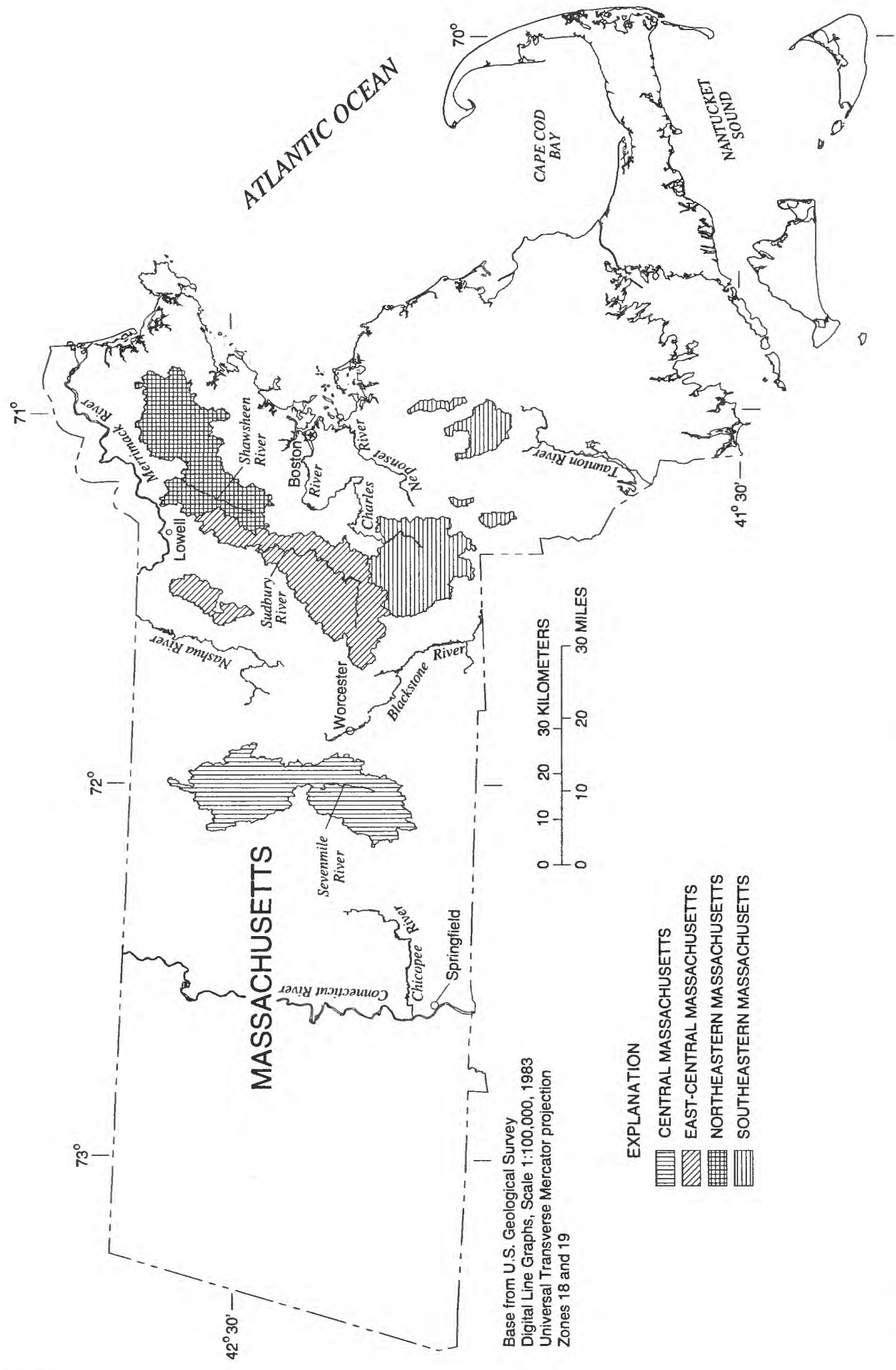

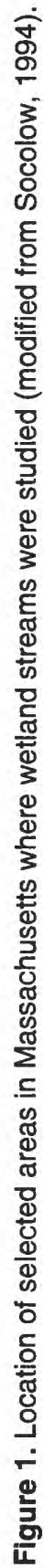


EXPLANATION

\section{-.- DRAINAGE-BASIN DIVIDE \\ DATA-COLLECTION SITE AND NUMBER}

QA2 $\triangle$ Instantaneous discharge measurement. See table 4

${ }^{\text {QA3 }}$ Water-quality data, single or multiple samples. See tables $1,4,6$, and 7

SITE IN A PRIMARY REACH-See table 1

SITE IN A SUBORDINATE REACH-See table 1
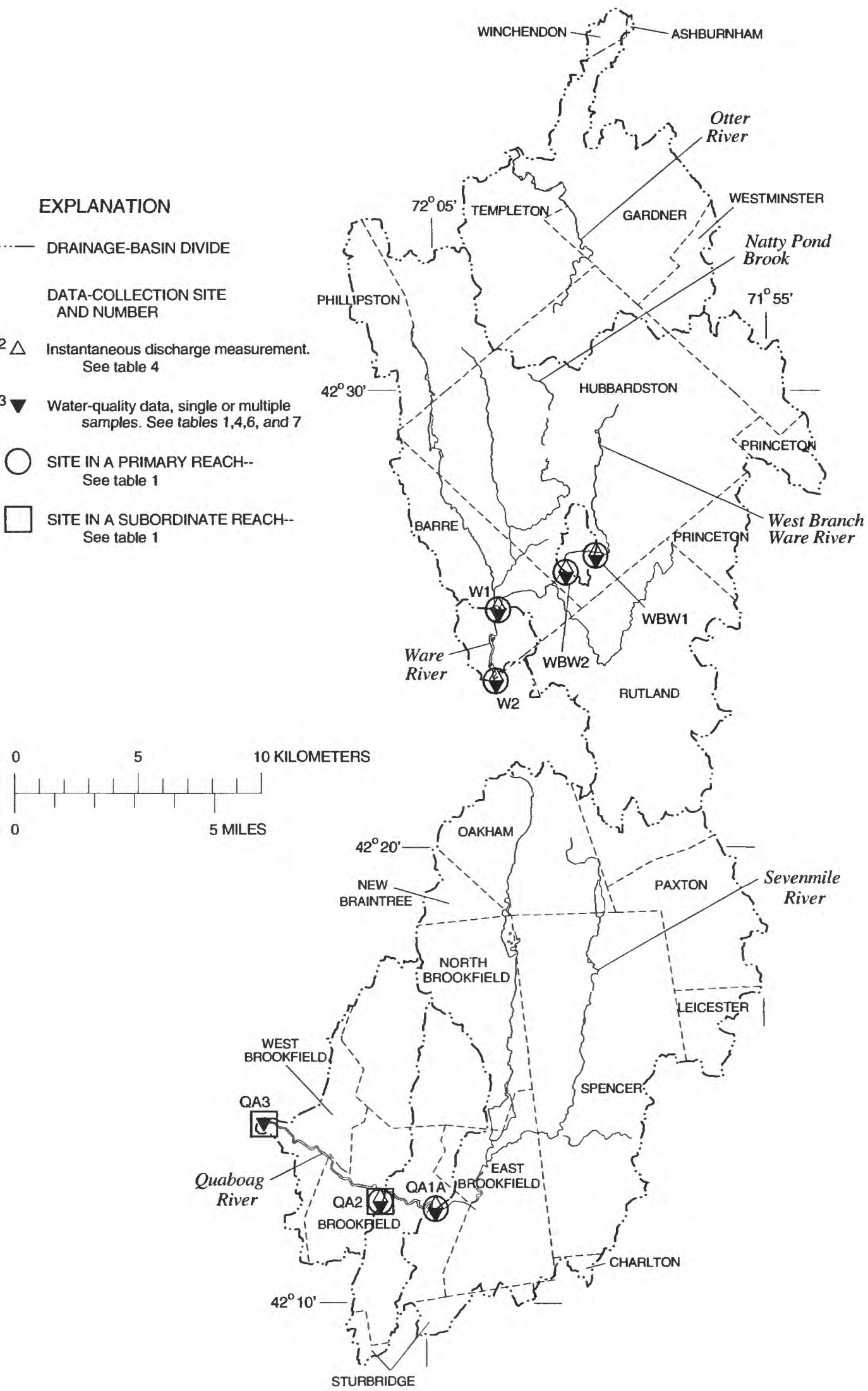

Figure 2. Location of hydrologic data-collection sites and contributing drainage-basin divides in central Massachusetts (modified from Socolow, 1994). 


\section{EXPLANATION \\ -..- DRAINAGE-BASIN DIVIDE DATA-COLLECTION SITE AND NUMBER \\ AS2 $\triangle$ Instantaneous discharge measurement. See table 4 \\ AS1 Water-quality data, single or multiple samples. See tables $1,4,6$, and 7 \\ SITE IN A PRIMARY REACH-- See table 1 \\ SITE IN A SUBORDINATE REACH-- See table 1}

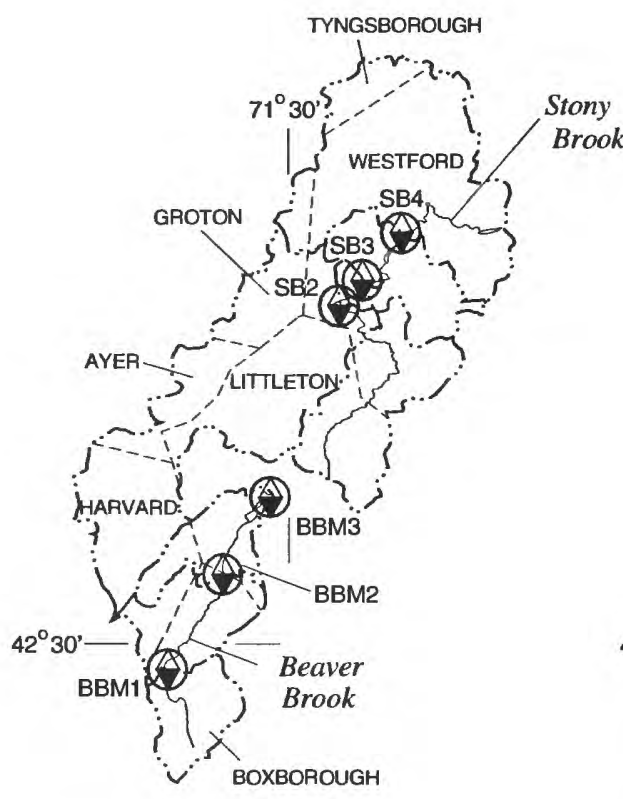

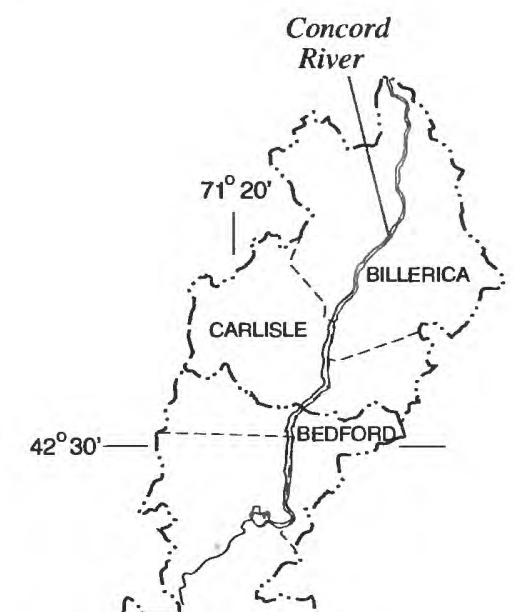

Concord

CONCORD, $j$

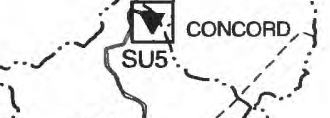

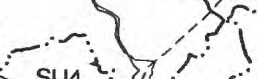<smiles>C1CCCC1</smiles><smiles>C1CCC1</smiles> 


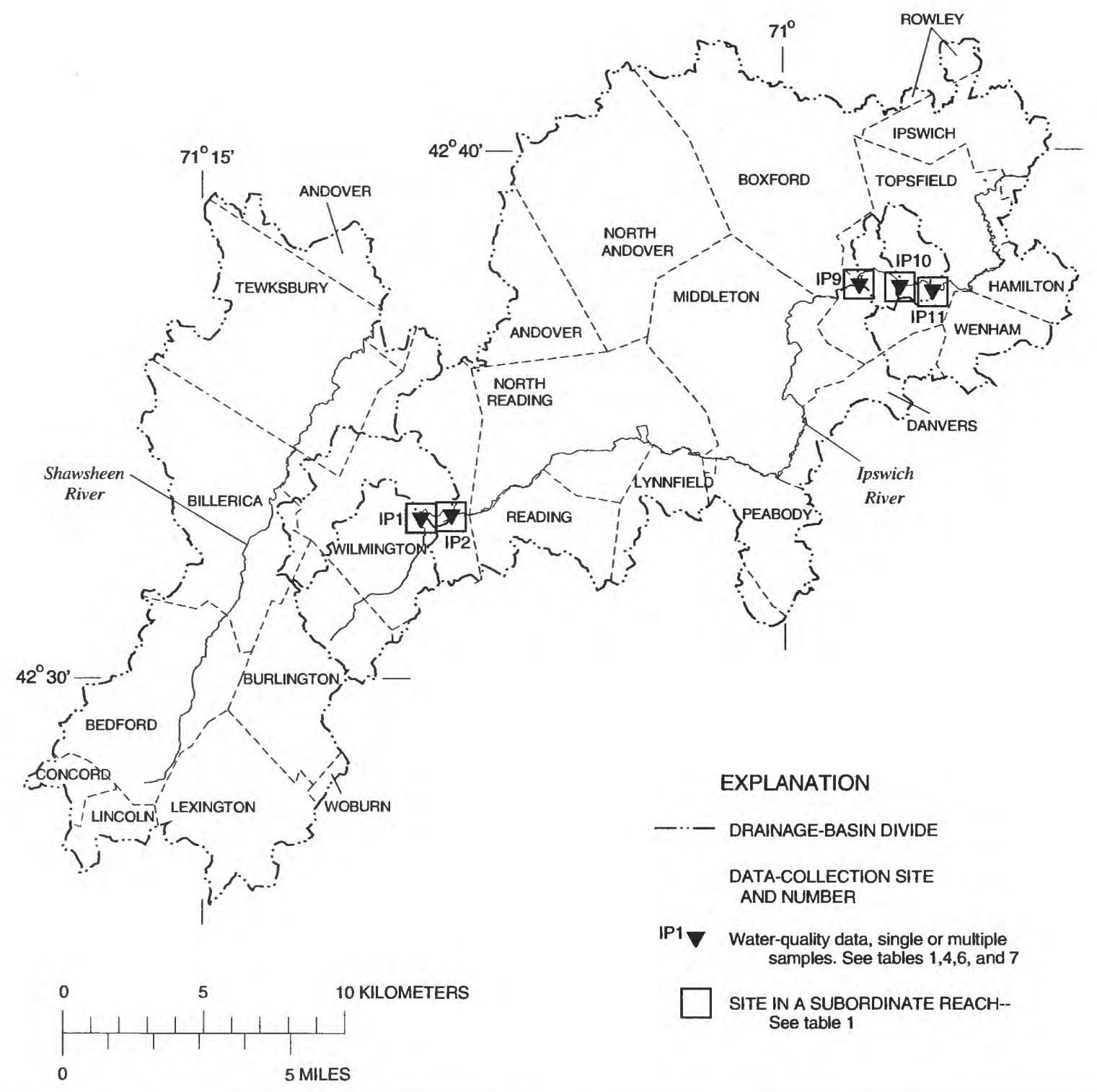

Figure 4. Location of hydrologic data-collection sites and contributing drainage-basin divides in northeastern Massachusetts (modified from Socolow, 1994). 


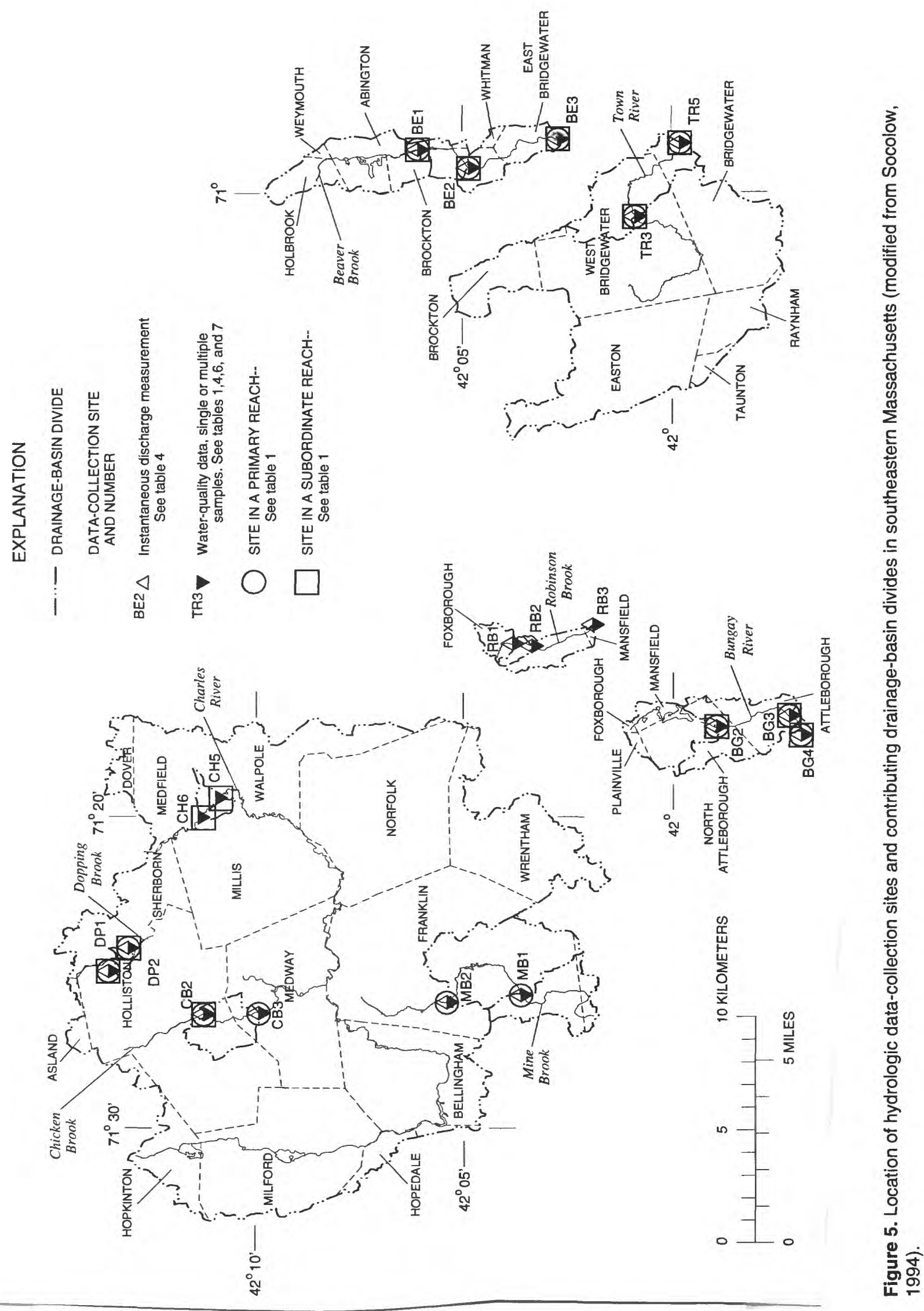




\section{Previous Studies}

Hydrology and water quality of New England streams, including wetland streams, are affected by regional geology, interactions between surface and ground water, and instream processes. The recharge or discharge of aquifers through organic deposits of wetlands or river-bottom sediments could have important implications for water quality. O'Brien $(1977,1980)$ demonstrated that a peat-filled wetland in Massachusetts surrounded by till recharged underlying deposits with $26,000 \mathrm{~m}^{3}$ of water for a 6-week period in August and September. The oxidation of organic matter in streambeds or aquifers beneath wetlands can deplete DO, which in turn can result in reduction by bacteria of nitrate, manganese, and ferric iron minerals, and sulfate, with a concurrent increase in the concentration of reduced chemical constituents, such as ammonium, ferrous iron, manganese, hydrogen sulfide, and methane. High concentrations of reduced chemical constituents have been reported in ground water associated with several wetlands in Massachusetts (Sammel, 1967; Motts and O'Brien, 1981; and Frimpter, 1988).

In an investigation of the effects of a wetland on the hydrology and water quality of a wetland-stream system in central Massachusetts, Suurballe (1992) determined that DOC and dissolved iron were directly proportional to the residence time of water in a wetland stream and inversely proportional to the concentration of DO. Suurballe (1992) concluded that the biochemical transformation of some water-quality constituents, such as nutrients, was facilitated by interaction within the wetland reach and the amount of available DO. Suurballe (1992) also determined that wetland size had a significant effect on stream loads of organic carbon and that stream reaches that have large ratios of wetland area to total intervening drainage area had negative net oxygen-productivity rates. Parker and Suurballe (1988) investigated oxygen-productivity rates and reaeration in a wetland-stream system in central Massachusetts. Productivity, respiration, drainage accrual, and diffusion constant were determined to be different in three reaches of the stream that had different wetland types, water-surface slopes, and color. Parker and Suurballe (1988) reported that productivity in each of these reaches appeared to be closely related to several wetland characteristics including drainage accrual, the humic content that affects light penetration in the stream, and the presence of riparian trees or shrubs that limit the amount of sunlight reaching the water surface.

\section{Acknowledgments}

The authors express appreciation to landowners, who granted access to streams to collect water-quality samples, and to Arthur Screpetis, Massachusetts Department of Environmental Protection, Office of Watershed Management, who encouraged the study of wetlands and streams.

\section{METHODS}

This section describes the study design and the evaluation of available data from Socolow (1994), along with the methods used for the measurement of basin, stream, and wetland characteristics, for the measurement of stream-water quality, and for data analysis.

\section{Study Design}

Physical, hydrologic, biologic, and water-quality data used in this investigation are published in Socolow (1994). These data were derived from two sources: (1) data collected and published by the MDEP, Division of Water Pollution Control, from 1962 through 1988 as part of their assessment of the surface water of the Commonwealth (Massachusetts Department of Environmental Protection, 1992) and (2) data collected by the USGS during 1988 and 1989 as part of this investigation. The MDEP data published in Socolow (1994) were evaluated by the USGS for the availability of various constituents and for the continuity of water-quality data and for the presence and character of wetlands in the stream reach between sampling sites. Water-quality data were collected by the USGS in 1988 and 1989 from wetland streams, many at the same sites previously sampled by the MDEP to supplement MDEP data. The wetland streams sampled in 1988 and 1989 were sampled for a wider range of chemical constituents than those represented in the MDEP data base. 
Data from Socolow (1994) for 96 upstream and downstream sampling sites on 72 stream reaches were evaluated for this investigation to determine whether or not water quality in each reach was affected by processes other than wetland factors. Wetland reaches from Socolow (1994) were screened to assure with reasonable confidence that the water-quality changes that were observed did occur in the wetland reaches under investigation. Schematic diagrams representing reaches that were not selected are illustrated in figure 6. Most of the reaches not selected fell into one of four categories:

1. Most of the riparian area along a stream reach was not classified as wetland on U.S. Fish and Wildlife Service (FWS) National Wetland Inventory (NWI) maps (fig. 6A).

2. The reach received inflows from tributaries that were not sampled, particularly when the contributing drainage area of the tributary was large or contained more wetland area than that contiguous to the study reach (fig. $6 B$ ).

3. The reach received point-source contributions from sewage-treatment plants or was just downstream of these discharges (fig. $6 C$ ).

4. Large lakes or impoundments existed between sampling sites (fig. 6D).

The remaining reaches represent a wide variety of wetland areas and types, canopy types, wetland reach slopes, reach lengths, contributing drainage areas, and stream discharges.

Reaches were further divided into primary and subordinate reaches based on data available for each sampling site. Primary reaches were those for which all needed data were available. These were predominantly reaches that were sampled by the USGS. Primary reaches were those that met the following minimum criteria:

1. Discharge was measured concurrently with sampling.

2. DO was measured for several days at hourly intervals concurrent with data for temperature, salinity, and barometric pressure. Temperature, salinity, and barometric pressure readings are required to calculate the percentage of saturation of DO.
3. Data were collected for major cations and anions, specific conductance, $\mathrm{pH}$, alkalinity, organic nitrogen, ammonia as nitrogen, and nitrite plus nitrate as nitrogen.

Subordinate reaches were those for which some of these data were missing or sparse, but where enough data existed for some inferences to be made, and included reaches that were sampled by the USGS and MDEP.

As a result of the screening process just described, data from 22 wetland reaches on 15 streams in central and eastern Massachusetts were selected for analysis. For purposes of analysis, these reaches were divided into 15 primary and 15 subordinate reaches (table 1 ), as previously described.

\section{Measurement of Basin, Stream, and Wetland Characteristics}

Physical and biologic characteristics of the selected wetland stream reaches and surrounding wetland areas were measured onsite or were digitized from FWS NWI maps. Measured or calculated characteristics included reach length, contributing drainage areas to wetland reaches, wetland reach slope, channel width, stream velocity and stream discharge, times of travel, wetland classification, area of wetlands, and shading by canopy.

Reach lengths and contributing drainage areas to wetland reaches were digitized from 1:24,000- or $1: 25,000$-scale USGS topographic maps. Reach lengths were defined by upstream and downstream sampling sites. Contributing drainage areas were defined as the area that drains to the reaches defined by the upstream and downstream sampling sites. Sampling sites were selected at or near locations where bridges crossed wetland streams. In most cases, the location of sampling sites did not coincide with the beginning or end of a wetland complex. Wetland reach slopes were calculated from USGS topographic maps (7.5 minute) and from digitized data of reach lengths. In streams sampled by the USGS, channel widths were measured at sampling sites and also at representative cross sections during initial reconnaissance of the stream reaches. Stream velocities for the reaches were calculated during measurement of discharge at upstream and downstream sampling sites. Times of travel for the reaches were estimated using reach lengths divided by average stream velocities. 



Figure 6. Wetland reaches that were not selected for this investigation. $(A)$ A stream reach where most of the riparian area along a stream is not classified as wetland. $(B)$ A stream reach that received tributary inflow that was not sampled. (C) A stream reach that received point source contributions from sewage-treatment plants or just downstream of these discharges. (D) A stream reach where large lakes or impoundments existed between sampling sites. 
Table 1. Information for selected wetland-stream sampling sites in central and eastern Massachusetts

[Reach designation: 1, primary; 2, subordinate. USGS, U.S. Geological Survey; MDEP, Massachusetts Department of Environmental Protection. --, no data]

\begin{tabular}{|c|c|c|c|c|}
\hline $\begin{array}{c}\text { Stream name } \\
\text { (river basin name) } \\
\text { and site No. }\end{array}$ & $\begin{array}{l}\text { USGS } \\
\text { site No. }\end{array}$ & $\begin{array}{l}\text { MDEP } \\
\text { site No. }\end{array}$ & Location & Reach designation \\
\hline
\end{tabular}

\section{Central Massachusetts (fig. 2)}

Quaboag River

(Ware)

$\begin{array}{lccll}\text { QA1A } & 01175745 & -- & \text { Quaboag Pond outlet, East Brookfield } & 1 \\ \text { QA2 } & 01175765 & \text { QA04 } & \text { Fiskdale Road, Brookfield } & 1,2 \\ \text { QA3 } & -- & \text { QA05 } & \text { Route 67, West Brookfield } & 2\end{array}$

Ware River

(Chicopee)

$\begin{array}{llclr}\text { W1 } & 01172880 & - & \text { Covered Bridge Road, Barre } & 1 \\ \text { W2 } & 01172940 & \text { WA01 } & \text { Route 122, Barre } & 1\end{array}$

West Branch

Ware River

(Ware)

\begin{tabular}{llllll} 
WBW1 & 01172396 & - & Twin Hill Road, Hubbardston & 1 & \\
WBW2 & 01172398 & -- & Brigham Road, Hubbardston & 1 & \\
\hline
\end{tabular}

\section{East-Central Massachusetts (fig. 3)}

Assabet River

(Concord)

\begin{tabular}{|c|c|c|c|}
\hline ASl & -- & AS01 & Augmentation Pond dam intake, Westborough \\
\hline AS2 & 01096602 & $\mathrm{AS} 02$ & Maynard Street, Westborough \\
\hline
\end{tabular}

Beaver Brook

(Merrimack)

BBMl

01096534

$--$

Swanson Road, Boxborough

1

BBM2

01096535

$--$

Harvard Sportsman's Club, Boxborough

1

BBM3

01096537

Harwood Avenue, Littleton

2

Stony Brook

(Merrimack)

SB2

$01096539 \quad$ ST04

Route 225, Westford

1,2

SB3

$01096540 \quad$ ST05

Town Farm Road, Westford

1,2

SB4

01096541

ST06

Broadway Street, Westford

1

Sudbury River

(Concord)

SU4

$\begin{array}{ll}-- & \text { SU09 }\end{array}$

SU10

Route 117, Lincoln

2

SU5

$-$

Nashawtuc Road, Concord

2 
Table 1. Information for selected wetland-stream sampling sites in central and eastern MassachusettsContinued

\begin{tabular}{|c|c|c|c|c|}
\hline $\begin{array}{l}\text { Stream name, } \\
\text { (river basin name) } \\
\text { and site No. }\end{array}$ & $\begin{array}{c}\text { USGS } \\
\text { site No. }\end{array}$ & $\begin{array}{l}\text { MDEP } \\
\text { site No. }\end{array}$ & Location & Reach designation \\
\hline \multicolumn{5}{|c|}{ Northeastern Massachusetts (fig. 4) } \\
\hline \multicolumn{5}{|l|}{$\begin{array}{l}\text { Ipswich River } \\
\text { (Ipswich) }\end{array}$} \\
\hline IP1 & -- & 101 & Wildwood Street, Wilmington & 2 \\
\hline IP2 & -- & 102 & Woburn Street, Wilmington & 2 \\
\hline IP9 & -- & 109 & Rowley Bridge Road, Topsfield & 2 \\
\hline IP10 & -- & $\mathrm{I} 10$ & Salem Road, Topsfield & 2 \\
\hline IP11 & -- & I11 & Route 97, Topsfield & 2 \\
\hline
\end{tabular}

Southeastern Massachusetts (fig. 5)

Beaver Brook

(Taunton)

$\begin{array}{lll}\text { BE1 } & 01106445 & \text { BE01 } \\ \text { BE2 } & 01106450 & \text { BE02 } \\ \text { BE3 } & 01106460 & \text { BE03 }\end{array}$

Bungay River

(Ten Mile)

$\begin{array}{lll}\text { BG2 } & 01109365 & \text { BG03 } \\ \text { BG3 } & 01109369 & \text { BG04 } \\ \text { BG4 } & 01109375 & \text { BG05 }\end{array}$

Charles River

(Charles)

$$
\text { CH5 }
$$

Chicken Brook

(Charles)

CB2 01103250

CB3

Dopping Brook

(Charles)

$$
\text { DP1 }
$$

DP2

Mine Brook

(Charles)

MB1

MB2

Town River

(Taunton)
$-$

$-$

01103251

01103384

01103386

01103229

01103235

$01107085 \quad$ TW03

01107100 TW05

Groveland Street, Brockton

1,2

Crescent Street, Brockton

1,2

Belmont Street, East Bridgewater

1,2

Below fish hatchery, North Attleborough $\quad 1,2$

Holden Street, Attleborough $\quad 1,2$

North Main Street, Attleborough $\quad 1,2$

Route 109, Medfield

2

Dover Street, Medfield

2

Routes 16 and 126, Holliston $\quad 1,2$

Lovering Street, Medway $\quad 1,2$

Brook Street, Holliston $\quad 1,2$

Whitney Street, Holliston $\quad 1,2$

Grove Street, Franklin 1

Route 140, Franklin

1

South Street, West Bridgewater $\quad 1,2$

Route 18, Bridgewater 
Wetlands were classified by type according to the system currently used by the FWS to classify wetlands in the United States (Cowardin and others, 1979). In this system, wetlands are classified on the basis of vegetation, soils, and hydrology. The area of wetlands in the contributing drainage area and the length of different types of riparian wetlands along the reaches were digitized from FWS NWI maps.

Stream canopies were designated as shaded, open, or partially shaded depending on the FWS wetland classification as indicated on NWI maps, on stream width, and on available onsite data. Streams of narrow width (less than about $10 \mathrm{~m}$ ) were considered to be shaded by their canopies if the riparian vegetation on NWI maps was forested upland or classified as palustrine forested (fig. 7A) or palustrine-forested and scrub-shrub wetlands. Streams were considered to be exposed to sunlight and to have open canopies if riparian wetlands on NWI maps were classified as palustrine emergent or scrub-shrub/emergent (fig. 7B). In addition, streams were considered partially shaded if wetlands were a mix of palustrine scrub-shrub and emergent wetlands, and shaded if the stream had an east-west orientation and upland or forested wetlands on the southern side.

\section{Measurement of Stream-Water Quality}

Data-collection methods used by the USGS and MDEP are detailed in Socolow (1994). Data collected by the USGS follow standard techniques that are published in a series of Techniques of Water-Resources Investigations manuals. Water samples for most constituents that were collected by the USGS were collected using a fluvial sediment-sampling technique called depth integration (Guy and Norman, 1970). Use of this technique requires depth-integrating samplers to be lowered and raised at a uniform rate throughout the depth of a stream cross section. The water-sediment mixture accumulates from all points in the sampled depth so that at every point an incremental volume of the mixture is collected that is proportional to the flow velocity at that point. This technique ensures that samples collected for analysis of chemical constituents contain representative subsamples of both the dissolved and suspended material that pass through the stream cross section at the time of sampling.

Streamflow values are either from measurements made at the time of sample collection or from a stagedischarge rating (Rantz and others, 1982). Specific conductance and $\mathrm{pH}$ were measured using methods described by Wood (1976). Samples collected by the USGS for water temperature and DO were measured at a single point in the stream. DO measurements were made using a DO meter and techniques described in Fishman and Friedman (1985). Continuous hourly temperature and DO data were recorded by multiconstituent monitors (Socolow, 1994). Water-quality analyses for turbidity and alkalinity (fixed endpoint to 4.0 standard $\mathrm{pH}$ units) were done at the USGS laboratory in Marlborough, Massachusetts. Samples requiring suspendedsediment determinations were analyzed at the USGS laboratory in Harrisburg, Pennsylvania; analysis methods for major solutes are described by Skougstad and others (1979).

Samples collected for laboratory analyses were preserved onsite and immediately shipped to the appropriate USGS laboratories. Sample preservation and analytical methods used by the USGS are described in Fishman and Friedman (1985), Wershaw and others (1987), and Britton and Greeson (1989).

The MDEP data were collected using standard techniques developed or adopted by the MDEP. Sample preservation and analytical methods used by the MDEP are described in Socolow (1994). Samples collected by the MDEP were either grab samples from a single sampling point or a composite of samples collected at multiple points in a stream cross section.

In any water-quality investigation, the issues of quality assurance and quality control need to be addressed. Methods for collection of water-quality samples differed between the MDEP and USGS. When data bases are combined, as in this investigation, the compatibility of data is a concern. On June 21,1988 , the MDEP and USGS sampled water at Robinson Brook, sites RB1, 2, and 3 (fig. 5). The resulting sample values were compared and used to assess the net effect of differences in sample-collection techniques, sample handling procedures, and laboratory analyses on waterquality data results. The sample values and respective collecting agencies are listed in table 2 . Results of analyses demonstrated that data generally were compatible, but that there were differences for certain constituents, particularly ammonia, phosphorus, and iron. Most MDEP analyses for ammonia as nitrogen and kjeldahl nitrogen were less than those collected by the USGS. In all cases, concentrations for dissolved iron were higher for MDEP analyses than for USGS analyses. 


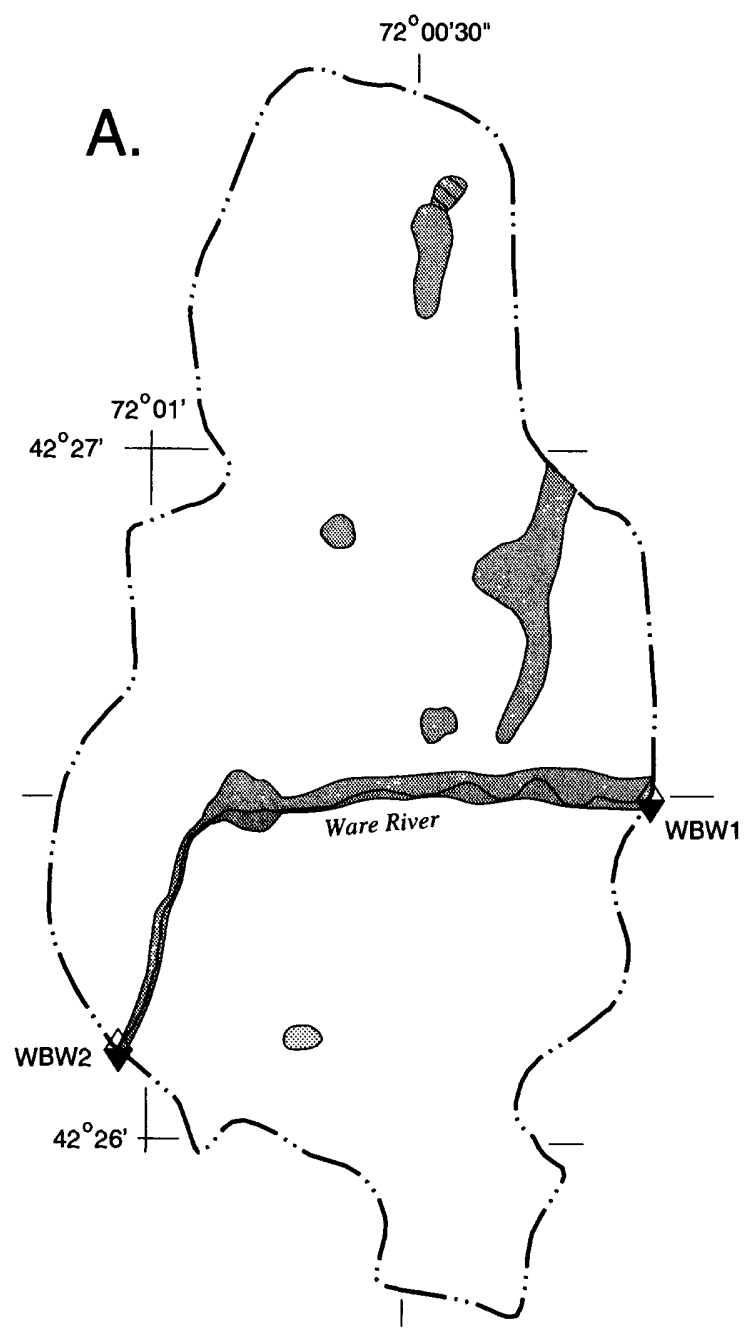

Base modified from U.S. Geological Survey National Wetlands Inventory

1:24,000 Barre, Massachusetts, 1969

Polyconic projection

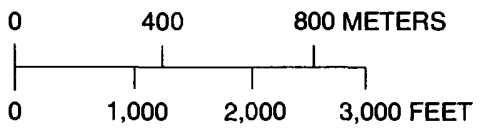

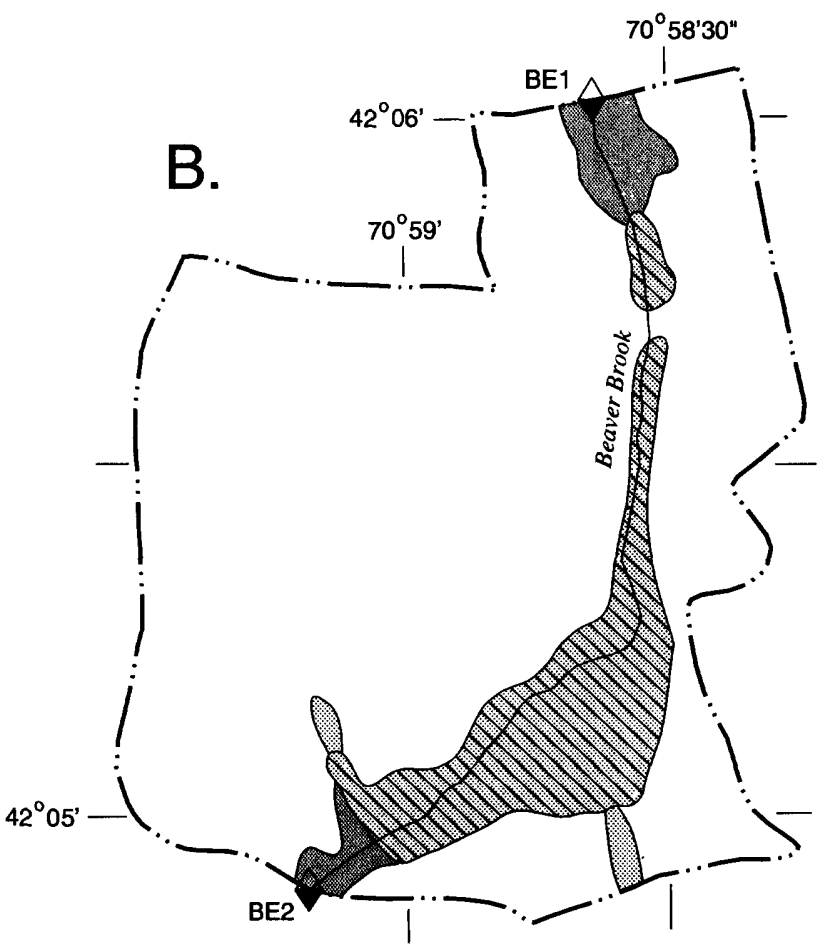

Base modified from U.S. Geological Survey

National Wetlands Inventory

1:24,000 Whitman, Massachusetts, 1977

Polyconic projection

\section{EXPLANATION}

PALUSTRINE SYSTEM

1.20 Forested

DIV Scrub-Shrub

Emergent

$\square$ UPLAND SYSTEM

$-\cdots-\underset{\text { SUUFACE DRAINAGE-BASIN }}{\text { SOUNARY }}$

BE1 $\triangle$ STREAMFLOW-GAGING SITE AND NUMBER

WBW2 $\nabla$ STREAM WATER-QUALITY SITE AND NUMBER

WBW2 Number indicates site number used in tables

Figure 7. Wetland reach dominated by (A) palustrine forested wetlands (West Branch Ware River, sites WBW1-2, table 1) and (B) palustrine scrub-shrub and emergent wetlands (Beaver Brook, Taunton Basin, sites BE1-2, table 1), central and eastern Massachusetts. 
Table 2. Comparison of quality-assurance data for MDEP and USGS samples collected from Robinson Brook, eastern Massachusetts, June 21, 1988

[Location of sites are shown in figure 5. MDEP, Massachusetts Department of Environmental Protection; USGS, U.S. Geological Survey. $\mu \mathrm{S} / \mathrm{cm}$, microsiemen per centimeter at $25^{\circ} \mathrm{C}$; NTU, nephelometric-turbidity unit; $\mathrm{mg} / \mathrm{L}$, milligram per liter]

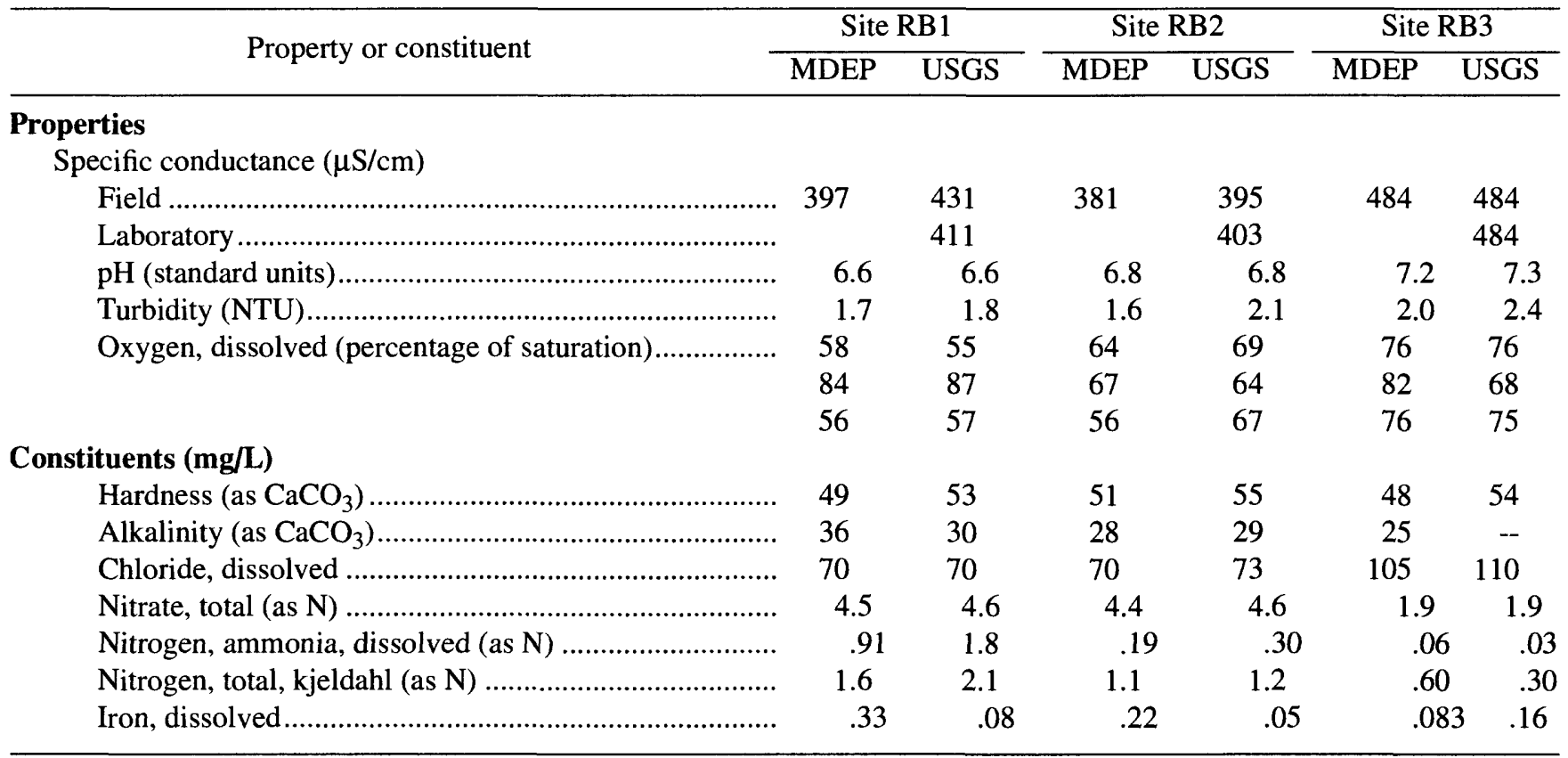

\section{Analysis of Data}

Nonparametric statistical techniques were used to check for significant differences between concentrations and loads from upstream and downstream sampling sites and to compare stream and wetland characteristics to stream-water quality. Nonparametric methods were used for the analysis of water-quality data because the large number of analyses with concentrations less than the minimum reporting level and the occasional high concentrations result in skewed distributions for most data (Helsel and Hirsch, 1992). Differences in water quality that occur between upstream and downstream sampling sites can be depicted by construction of boxplots that show concentrations and loads of selected constituents, and stream and wetland characteristics. Water-quality variables displayed for the stream and wetland characteristics included date or season, contributing drainage area to the stream reach, area of wetlands in the contributing area, predominant wetland type (by area) in the contributing area, canopy shading as determined by predominant wetland type along the riparian zone, discharge, reach length, and reach slope. For comparison purposes, boxplots were constructed that compared groups of the measured characteristics. Because of the small size of the data set, groups of data, such as streams having small and large discharges, or small and large wetland areas, were selected that would divide the data into two or three portions of approximately equal size. These groups then were compared to water-quality constituents and tested for significant differences. The group criteria are given in table 3.

Two nonparametric tests, the sign test and Wilcoxon signed-rank test (Helsel and Hirsch, 1992), were used to test for significant differences between upstream and downstream data pairs. Both of these tests determine the probability that the difference between the medians is due to chance. The null hypothesis $\left(\mathrm{H}_{0}\right)$ is that constituent concentrations are equally likely to be higher or lower for upstream and downstream sampling sites. For upstream and downstream data pairs $\left(X_{i}, Y_{i}\right.$, where $i=1, \ldots \mathrm{n})$, the sign test computes the number of 
Table 3. Group criteria for basin, stream, and wetland characteristics

[Wetland classifications are from the U.S. Fish and Wildlife classification (Cowardin and others, 1979). Group criteria: P, palustrine; fo, forested; ss, scrub-shrub; em, emergent; ow, open water; R, riverine; and U, upland. $\mathrm{km}$, kilometer; $\mathrm{km}^{2}$, square kilometer; $\mathrm{m}^{3} / \mathrm{s}$, cubic meter per second]

\begin{tabular}{|c|c|c|}
\hline Characteristic & Group & Group criteria \\
\hline \multirow[t]{3}{*}{ Season } & Early summer & June 21 through July 12. \\
\hline & Mid-summer & July 13 through August 8. \\
\hline & Late summer & August 9 through September 12. \\
\hline \multirow[t]{3}{*}{ Contributing drainage area } & Small & 0 to $5 \mathrm{~km}^{2}$. \\
\hline & Medium & 6 to $10 \mathrm{~km}^{2}$. \\
\hline & Large & Greater than $10 \mathrm{~km}^{2}$. \\
\hline \multirow[t]{2}{*}{ Wetland area } & Small & 0 to $5 \mathrm{~km}^{2}$. \\
\hline & Medium/large & Greater than $5 \mathrm{~km}^{2}$. \\
\hline \multirow[t]{3}{*}{ Wetland type } & Grassy-open & 66 to 100 percent of wetland area is classified as (Pss/em, Pem, Pow, R). \\
\hline & Mixed & $\begin{array}{l}33 \text { to } 66 \text { percent of wetland area is classified as (Pss/em, Pem, Pow, R) or } \\
\text { (Pfo, Pfo/ss, Pss). }\end{array}$ \\
\hline & Woody-shaded & 66 to 100 percent of wetland area is classified as (Pfo, Pfo/ss, Pss). \\
\hline \multirow[t]{3}{*}{ Canopy shading 1} & Shaded & $\begin{array}{l}66 \text { to } 100 \text { percent of riparian wetlands are classified as } \\
\text { (Pfo, Pfo/ss, Pss, U). }\end{array}$ \\
\hline & Partial & $\begin{array}{l}33 \text { to } 66 \text { percent of riparian wetlands are classified as (Pfo, Pfo/ss, Pss, U) or } \\
(\mathrm{Pem}, \mathrm{Pem} / \mathrm{ss}) \text {. }\end{array}$ \\
\hline & Open & 66 to 100 percent of riparian wetlands are classified as $(\mathrm{Pem}, \mathrm{Pem} / \mathrm{ss})$. \\
\hline \multirow[t]{3}{*}{ Discharge } & Small & 0.01 to $0.10 \mathrm{~m}^{3} / \mathrm{s}$. \\
\hline & Medium & 0.11 to $1.0 \mathrm{~m}^{3} / \mathrm{s}$. \\
\hline & Large & 1.1 to $10 \mathrm{~m}^{3} / \mathrm{s}$. \\
\hline \multirow[t]{3}{*}{ Reach length } & Short & 0 to $2 \mathrm{~km}$. \\
\hline & Medium & 3 to $4 \mathrm{~km}$. \\
\hline & Long & 5 to $6 \mathrm{~km}$. \\
\hline \multirow[t]{2}{*}{ Reach slope } & Low & 0.0002 to 0.002 . \\
\hline & Medium & Greater than 0.002 . \\
\hline
\end{tabular}

\footnotetext{
${ }^{1}$ Also dependent on orientation.
}

positive and negative differences so that a difference between $X_{i}$ and $Y_{i}$ is detected without regard to the magnitude of the difference. The Wilcoxon signed-rank test computes the sum of the ranked differences and indicates whether or not the magnitude of the difference between paired data is significantly different from zero (Helsel and Hirsch, 1992). A $p$ value of less than 0.05 was selected to indicate significant difference.

\section{WATER QUALITY OF SELECTED WETLAND STREAMS}

This section describes basin, stream, and wetland characteristics, water quality, and the relation of basin, stream, and wetland characteristics to water quality for selected wetland streams in central and eastern Massachusetts. 


\section{Basin, Stream, and Wetland Characteristics}

Basin, stream, and wetland characteristics that were measured for each stream reach are given in table 4. These characteristics include the date of sampling, contributing drainage area to the reach, total area of wetlands in the contributing drainage area, percentage of canopy shading, stream discharge, reach length, reach slope, and predominant wetland classification (by area and reach length) in the contributing area.

Dates of sampling for this study ranged from June through September of 1988 and 1989. Sampling dates were divided into subgroups of early, middle, and late summer because several physical characteristics, such as temperature, light availability, stream discharge, growth of algae and macrophytes, and decomposition vary seasonally. These factors potentially can affect many water-quality constituents. Temperature has an inverse relation with the saturation concentration of DO and a direct relation to the rate of decomposition. Concentrations of DO at saturation are lower at warm temperatures than at cool temperatures. Thus, a relatively constant oxygen demand would have a proportionally greater effect during periods of warm temperature. If the oxygen demand were caused by biochemical oxygen demand (BOD) or sediment oxygen demand (SOD), this effect could be compounded in the summer because rates of decomposition also increase with temperature. For example, a temperature increase of $10^{\circ} \mathrm{C}$ can double the rate of decomposition and oxygen consumption. Light availability varies on a daily basis due to cloud cover and also varies seasonally. The availability of light decreases after June 21 and, as a result, production decreases in late summer. Temperatures and respiration, however, remain high throughout August, and respiration may surpass production in late summer.

Determination of the effect of wetlands on water quality also is strongly dependent on the timing of sampling relative to the stream discharge. For example, wetlands might be expected to have a different effect on sediment during periods of runoff than during base flow. Data for antecedent conditions prior to sampling for this study are unavailable. The selected streams primarily represent low-order streams. Stream discharges ranged from less than 0.01 to more than $3.0 \mathrm{~m}^{3} / \mathrm{s}$. Median discharges were $0.03 \mathrm{~m}^{3} / \mathrm{s}$ for upstream sites and 0.08 $\mathrm{m}^{3} / \mathrm{s}$ for downstream sites. Low streamflows in summer can be accompanied by small stream cross-sectional areas, reduced mixing, slowed velocities, and lengthened traveltimes. These conditions could result in lowered rates of reaeration and increased contact times between stream water and the organic material in wetland reaches. As a result of increased contact times, biochemical reactions have a greater opportunity to alter water quality. Low flows, high temperatures, and nutrient enrichment are conducive to rapid growth of algal communities (blooms). The die-off of these phytoplankton blooms in late summer can create a large oxygen demand. The magnitude of stream discharge also can have a large effect on DO dynamics. For instance, a deep sluggish river may exhibit little diurnal change in oxygen concentration, whereas a shallow stream may have large diurnal fluctuations in DO. The small change in oxygen concentration in the deep river, however, may indicate a larger change in oxygen metabolism under a square meter of the surface than a large change in a shallow river (Hoskin, 1959).

Wetland areas in the selected reaches ranged from 0.07 to $1.62 \mathrm{~km}^{2}$ or as much as 17 percent of the contributing area to the stream reach. Median wetland area was $0.62 \mathrm{~km}^{2}$. Because selected sampling sites were at or near bridges crossing wetland streams, most of the upstream and downstream sampling sites were not located at the beginning or end of wetland complexes.

Streams in the study area are shaded by forested and scrub-shrub vegetation and also by surrounding forested upland. In the absence of onsite data, canopy shading was estimated from NWI maps. This method can only approximate canopy shading because of changes in vegetation and stream course, variations in stream width and canopy cover, the difficulty of estimating the effects of surrounding hills from a map, and the resolution of the NWI maps.

Reach slope can be an indicator of stream velocity. Reach slopes for the selected wetland streams ranged from 0.0002 to $0.005 \mathrm{~m} / \mathrm{m}$. Median slope was 0.001 $\mathrm{m} / \mathrm{m}$. Low slopes and low stream velocities can result in long times of travel in wetland reaches. Reaeration, an important source of DO to streams, is reduced by low 
slopes (Parker and DeSimone, 1992). Lengthened time of travel because of low slopes in wetland streams and restrictions in flow generated by wetland vegetation may be the principal means by which wetlands affect water quality.

Using the FWS classification (Cowardin and others, 1979), wetlands along streams in Massachusetts are commonly classified as having a combination of several different wetland types, such as palustrine forested, scrub-shrub, and emergent wetlands. For the selected wetland streams, the most common wetland type by area was palustrine forested wetlands, followed by mixed scrub-shrub and emergent wetlands, mixed forested and scrub-shrub wetlands, scrub-shrub wetlands, emergent wetlands, open-water wetlands, and emergent and open-water wetlands.

Table 4. Basin and stream characteristics and wetland classifications for selected wetland streams, central and eastern Massachusetts, 1988-89

[Wetland classifications are from the U.S. Fish and Wildlife classification (Cowardin and others, 1979). P, palustrine; fo, forested; ss, scrub shrub; em, emergent; ow, open water; R, riverine; U, upland. --, not measured. $\mathrm{km}^{2}$, square kilometer; $\mathrm{m}^{3} / \mathrm{s}$, cubic meter per second; $\mathrm{km}$, kilometer; $\mathrm{m} / \mathrm{m}$, meter per meter]

\begin{tabular}{cccc}
\hline & & \multicolumn{2}{c}{ Basin characteristics } \\
\cline { 3 - 4 } $\begin{array}{c}\text { Stream name } \\
\text { (river basin } \\
\text { name) }\end{array}$ & $\begin{array}{c}\text { Date of } \\
\text { sample } \\
\text { collec- } \\
\text { and site No. }\end{array}$ & $\begin{array}{c}\text { Contributing } \\
\text { drainage area }\end{array}$ & $\begin{array}{c}\text { Wetland } \\
\text { area } \\
\left(\mathrm{km}^{2}\right)\end{array}$ \\
\hline
\end{tabular}

\begin{tabular}{|c|c|c|c|}
\hline \multicolumn{4}{|c|}{ Central Massachusetts (fig. 2) } \\
\hline $\begin{array}{l}\text { Quaboag River } \\
\text { (Ware) } \\
\text { QA1A-2 }\end{array}$ & $8-02-88$ & 30.41 & 2.42 \\
\hline $\begin{array}{l}\text { Ware River } \\
\text { (Chicopee) } \\
\text { W1-2 }\end{array}$ & $6-28-88$ & 7.28 & .72 \\
\hline $\begin{array}{l}\text { West Branch } \\
\text { Ware River } \\
\text { (Ware) } \\
\text { WBW1-2 }\end{array}$ & $7-06-88$ & 3.38 & .18 \\
\hline
\end{tabular}

East-Central Massachusetts (fig. 3)

\section{Beaver Brook \\ (Merrimack)}

$\begin{array}{lrrr}\text { BBM1-2 } & 8-09-89 & 6.21 & 0.79 \\ \text { BBM2-3 } & 8-09-89 & 4.95 & .85\end{array}$

Stony Brook

(Merrimack)

$\begin{array}{lrrr}\text { SB2-3 } & 8-01-89 & .75 & .08 \\ \text { SB3-4 } & 8-01-89 & 6.47 & .07\end{array}$

\begin{tabular}{cccc}
\hline & & \multicolumn{2}{c}{ Basin characteristics } \\
\cline { 3 - 4 } $\begin{array}{c}\text { Stream name } \\
\text { (river basin } \\
\text { name) }\end{array}$ & $\begin{array}{c}\text { Date of } \\
\text { sample } \\
\text { collec- } \\
\text { tion }\end{array}$ & $\begin{array}{c}\text { Contributing } \\
\text { drainage area } \\
\left(\mathrm{km}^{2}\right)\end{array}$ & $\begin{array}{c}\text { Wetland } \\
\text { area } \\
\left(\mathrm{km}^{2}\right)\end{array}$ \\
\hline
\end{tabular}

\begin{tabular}{lccr}
\hline \multicolumn{3}{c}{ Southeastern Massachusetts (fig. 5) } \\
\hline $\begin{array}{l}\text { Beaver Brook } \\
\text { (Taunton) }\end{array}$ & & & \\
BE1-2 & $8-29-88$ & 3.04 & 0.45 \\
BE2-3 & $8-29-88$ & 6.84 & .97 \\
$\begin{array}{l}\text { Bungay River } \\
\text { (Ten Mile) }\end{array}$ & & & \\
BG2-3 & $6-21-89$ & 10.12 & .36 \\
BG3-4 & $6-21-89$ & .60 & .10 \\
$\begin{array}{l}\text { Chicken Brook } \\
\text { (Charles) }\end{array}$ & & & \\
CB2-3 & $7-25-89$ & 5.82 & .62 \\
$\begin{array}{l}\text { Dopping Brook } \\
\text { (Charles) }\end{array}$ & & & \\
$\begin{array}{l}\text { DP1-2 } \\
\text { Mine Brook }\end{array}$ & $7-18-89$ & .70 & .11 \\
(Charles) & & & \\
MB1-2 & $7-11-89$ & 17.6 & 1.62 \\
$\begin{array}{l}\text { Town River } \\
\text { (Taunton) }\end{array}$ & & & \\
TR3-5 & $9-12-89$ & 12.15 & 1.46
\end{tabular}


Table 4. Basin and stream characteristics and wetland classifications for selected wetland streams, central and eastern Massachusetts, 1988-89-Continued

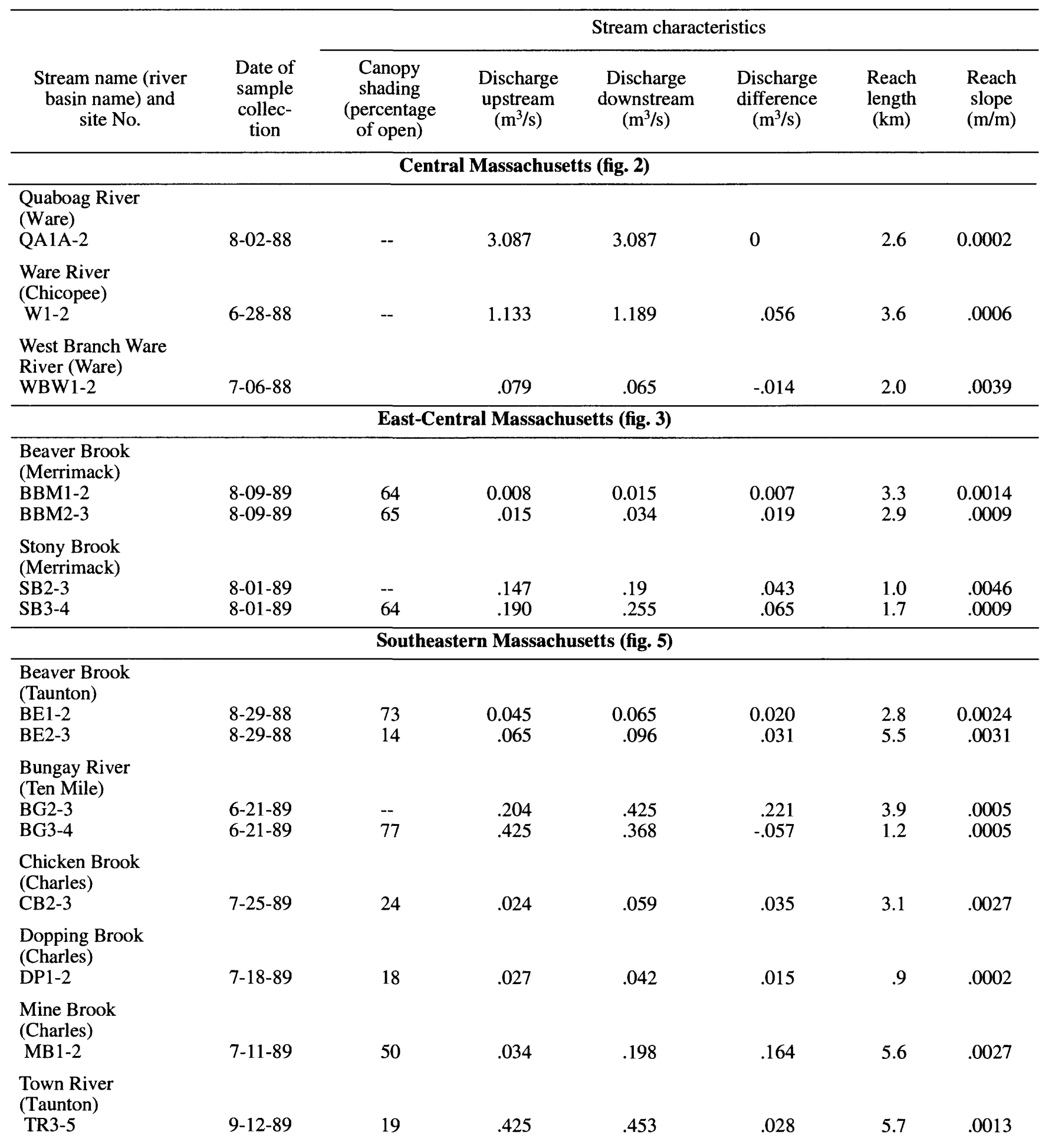


Table 4. Basin and stream characteristics and wetland classifications for selected wetland streams, central and eastern Massachusetts, 1988-89-Continued

Wetland classification (area in square kilometers)

\begin{tabular}{|c|c|c|c|c|c|c|c|c|}
\hline $\begin{array}{l}\text { Stream name } \\
\text { (river basin } \\
\text { name) and } \\
\text { site No. }\end{array}$ & $\begin{array}{l}\text { Date of } \\
\text { sample } \\
\text { collec- } \\
\text { tion }\end{array}$ & Pfo & Pfo/ss & Pss & Pss/em & Pem & Pem/ow & Pow \\
\hline
\end{tabular}

\section{Central Massachusetts (fig. 2)}

Quaboag River

(Ware)

QA1A-2

8-02-88

Ware River

(Chicopee)

W1-2

6-28-88 $\quad 0.49 \quad 0$

0.185

0.02

0.009

0

0.011

0.715

West Branch

Ware River

(Ware)

WBW1-2

7-06-88

.1730

0

0

$.004 \quad 0$

0

.177

East-Central Massachusetts (fig. 3)

Beaver Brook
(Merrimack)

BBM1-2

BBM2-3

$8-09-89$

0.234

0.204

0.065

0.222

0.042

.048

0
0

0.018

0.785

Stony Brook

(Merrimack)

SB2-3

8-01-89

8-01-89

.076

.067

$\begin{array}{lll}0 & 0 & 0 \\ 0 & 0 & 0\end{array}$

0
0

0
0

0

0

.076

Southeastern Massachusetts (fig. 5)

Beaver Brook

(Taunton)

BE1-2

BE2-3

8-29-88

0.087

0

0

.020

0.316

0.022

0
0

0.020

0.445

Bungay River

(Ten Mile)

BG2-3

BG3-4

6-21-89

6-21-89

--

$--$

$--$

.102

$--$

$--$

.102

Chicken Brook

(Charles)

CB2-3

7-25-89

.446

.036

.056

.053

0

.029

.620

Dopping Brook

(Charles)

DP1-2

7-18-89

.011

.049

0

.013

.034

0

0

.107

Mine Brook

(Charles)

MB1-2

7-11-89

.731

.059

.099

.46

.095

0

.174

1.618

Town River

(Taunton)

TR3-5

9-12-89 
Table 4. Basin and stream characteristics and wetland classifications for selected wetland streams, central and eastern Massachusetts, 1988-89-Continued

\begin{tabular}{|c|c|c|c|c|c|c|c|c|c|c|c|}
\hline \multirow{2}{*}{$\begin{array}{c}\text { Stream name } \\
\text { (river basin } \\
\text { name) and } \\
\text { site No. }\end{array}$} & \multirow{2}{*}{$\begin{array}{l}\text { Date of } \\
\text { sample } \\
\text { collec- } \\
\text { tion }\end{array}$} & \multicolumn{10}{|c|}{ Wetland classification (reach length, in kilometers) } \\
\hline & & Pfo & Pfo/ss & Pss & Pss/em & Pem & Pem/ow & Pow & $\mathbf{R}$ & $\mathbf{U}$ & Total \\
\hline \multicolumn{12}{|c|}{ Central Massachusetts (fig. 2) } \\
\hline $\begin{array}{l}\text { Quaboag } \\
\text { River } \\
\text { (Ware) } \\
\text { QA1A-2 }\end{array}$ & $8-02-88$ & -- & -- & -- & -- & -- & -- & -- & -- & -- & 2,565 \\
\hline $\begin{array}{l}\text { Ware River } \\
\text { (Chicopee) } \\
\text { W1-2 }\end{array}$ & $6-28-88$ & -- & -- & -- & -- & -- & -- & -- & -- & -- & 3,617 \\
\hline $\begin{array}{l}\text { West Branch } \\
\text { Ware River } \\
\text { (Ware) }\end{array}$ & & & & & & & & & & & \\
\hline WBW1-2 & $7-06-88$ & -- & -- & -- & -- & -- & -- & -- & -- & -- & 1,950 \\
\hline \multicolumn{12}{|c|}{ East-Central Massachusetts (fig. 3) } \\
\hline $\begin{array}{l}\text { Beaver Brook } \\
\text { (Merrimack) } \\
\text { BBM1-2 } \\
\text { BBM2-3 }\end{array}$ & $\begin{array}{l}8-09-89 \\
8-09-89\end{array}$ & $\begin{array}{l}242 \\
675\end{array}$ & $\begin{array}{l}0 \\
0\end{array}$ & $\begin{array}{r}666 \\
0\end{array}$ & $\begin{array}{l}1,820 \\
1,866\end{array}$ & $\begin{array}{r}126 \\
0\end{array}$ & $\begin{array}{l}0 \\
0\end{array}$ & $\begin{array}{r}168 \\
0\end{array}$ & $\begin{array}{l}0 \\
0\end{array}$ & $\begin{array}{l}270 \\
315\end{array}$ & $\begin{array}{l}3,292 \\
2,856\end{array}$ \\
\hline $\begin{array}{l}\text { Stony Brook } \\
\text { (Merrimack) }\end{array}$ & & & & & & & & & & & \\
\hline $\begin{array}{l}\text { SB2-3 } \\
\text { SB3-4 }\end{array}$ & $\begin{array}{l}8-01-89 \\
8-01-89\end{array}$ & $\begin{array}{l}658 \\
318\end{array}$ & $\begin{array}{l}0 \\
0\end{array}$ & $\begin{array}{l}0 \\
0\end{array}$ & $\begin{array}{r}0 \\
262\end{array}$ & $\begin{array}{l}0 \\
0\end{array}$ & $\begin{array}{l}0 \\
0\end{array}$ & $\begin{array}{r}0 \\
852\end{array}$ & $\begin{array}{l}0 \\
0\end{array}$ & $\begin{array}{l}334 \\
299\end{array}$ & $\begin{array}{r}992 \\
1,731\end{array}$ \\
\hline \multicolumn{12}{|c|}{ Southeastern Massachusetts (fig. 5) } \\
\hline $\begin{array}{l}\text { Beaver Brook } \\
\text { (Taunton) } \\
\text { BE1-2 } \\
\text { BE2-3 }\end{array}$ & $\begin{array}{l}8-29-88 \\
8-29-88\end{array}$ & $\begin{array}{r}543 \\
2,486\end{array}$ & $\begin{array}{l}0 \\
0\end{array}$ & $\begin{array}{r}0 \\
457\end{array}$ & $\begin{array}{r}1,757 \\
0\end{array}$ & $\begin{array}{r}0 \\
714\end{array}$ & $\begin{array}{l}0 \\
0\end{array}$ & $\begin{array}{r}259 \\
50\end{array}$ & $\begin{array}{r}0 \\
761\end{array}$ & $\begin{array}{l}200 \\
996\end{array}$ & $\begin{array}{l}2,759 \\
5,464\end{array}$ \\
\hline $\begin{array}{l}\text { Bungay River } \\
\text { (Ten Mile) } \\
\text { BG2-3 } \\
\text { BG3-4 }\end{array}$ & $\begin{array}{l}6-21-89 \\
6-21-89\end{array}$ & 0 & 0 & 0 & 944 & 0 & 0 & 0 & 190 & 89 & 1,223 \\
\hline $\begin{array}{l}\text { Chicken } \\
\text { Brook } \\
\text { (Charles) } \\
\text { CB2-3 }\end{array}$ & $7-25-89$ & 1,116 & 0 & 0 & 0 & 190 & 0 & 567 & 0 & 1,295 & 3,168 \\
\hline $\begin{array}{l}\text { Dopping } \\
\text { Brook } \\
\text { (Charles) } \\
\text { DP1-2 }\end{array}$ & $7-18-89$ & 488 & 0 & 0 & 171 & 0 & 0 & 0 & 0 & 269 & 928 \\
\hline $\begin{array}{l}\text { Mine Brook } \\
\text { (Charles) } \\
\text { MB1-2 }\end{array}$ & $7-11-89$ & 1244 & 0 & 257 & 1,959 & 123 & 0 & 720 & 224 & 1,116 & 5,643 \\
\hline $\begin{array}{l}\text { Town River } \\
\text { (Taunton) } \\
\text { TR3-5 }\end{array}$ & $9-12-89$ & -- & -- & -- & -- & -- & -- & -- & -- & -- & -- \\
\hline
\end{tabular}




\section{Water Quality}

Water-quality data from primary wetland reaches are shown in a trilinear diagram (fig. 8). The trilinear diagram displays the composition of basic cations and anions in water from upstream and downstream sampling sites. Water from most of the wetland reaches was similar in composition. The few exceptions include water from the Quaboag, Ware, and West Branch Ware Rivers, where sulfate concentrations were high relative to sulfate concentrations in other reaches. These rivers are in central Massachusetts, and the high sulfate composition may be attributed to the presence of sulfide minerals present in sulfidic schist, which underlies parts of these river basins (Rittmaster and Shanley, 1994). Water from Dopping Brook exhibited higher calcium and sulfate concentrations, and water from Stony Brook had slightly higher sulfate and lower chloride concentrations than other streams in the study areas. The major cationic components of rivers generally reflect the composition of associated rocks and the relative resistance of minerals to weathering, and the anions generally reflect the importance of various chemical and biochemical processes that have broken down the rock minerals, as well as chemical, biochemical, and physical processes that occur in the aquatic and surrounding environment (Hem and others, 1990).

Although most constituents in streams are relatively stable if hydrologic conditions are in a steady state, the concentration of DO can fluctuate substantially on a daily basis depending on weather conditions, time of day, and season. Sources of DO to a stream reach include DO carried into the reach from upstream and contributions to the reach from tributaries, ground water, reaeration, and primary production. Oxygen can be removed from streams by BOD, SOD, chemical oxygen demand (COD), discharge to the stream of water that has low DO, and respiration of plants and animals. Algae, phytoplankton, and macrophytes affect DO concentrations in streams predominantly through primary production and respiration. Production generally exceeds respiration during the day and is less than respiration at night. Consequently, DO concentrations typically increase during the day and decrease at night. However, not all aquatic vegetation similarly affects DO concentrations in streams. Oxygen produced by phytoplankton and submersed aquatic vegetation (algae) is released directly to the water column, whereas most oxygen produced by emergent macrophytes is released to the air.

DO data are difficult to compare to other waterquality data or data for stream and wetland characteristics because DO exhibits a wide range of variability and because instantaneous DO concentrations are dependent on the time of sampling. Similar DO concentrations could be measured in different streams even though the oxygen dynamics in the streams are entirely different. The percentage of saturation of DO differed greatly between the sampled streams in this study. Graphs that demonstrate the wide range of DO conditions that were measured are shown in figure 9. Each graph represents several days of hourly DO data. Graphs of Chicken Brook, sites CB2-3, show small daily DO fluctuations and a large decrease in DO saturation. Graphs of Beaver Brook (Taunton), sites BE2-3, show small daily fluctuations and an increase in DO saturation. In contrast, graphs of Mine Brook, sites MB2 and 3, and the West Branch Ware River, sites WBW1 and 2, depict large diel fluctuations, whereas the Quaboag River, sites QA1A and 2, has large diel fluctuations and is supersaturated during certain daytime hours.

The concentrations of dissolved organic phosphorus in water from the sampled wetland streams range from 0.01 to $0.13 \mathrm{mg} / \mathrm{L}$ with a median of 0.01 $\mathrm{mg} / \mathrm{L}$ (table 5). Low concentrations of phosphorus in the water column do not necessarily mean that there is little phosphorus in wetland-stream systems. Because phosphorus is taken up rapidly by plants, binds tightly to sediment, and is sorbed to iron complexes, concentrations of phosphorus commonly are low in the water column. Biologic cycling also is an important factor in the occurrence of other elements, such as potassium, silicon, nitrogen, iron, and manganese. Concentrations of these elements in stream water may decrease during periods of plant growth and increase during periods of vegetation dormancy (Likens and others, 1977). 


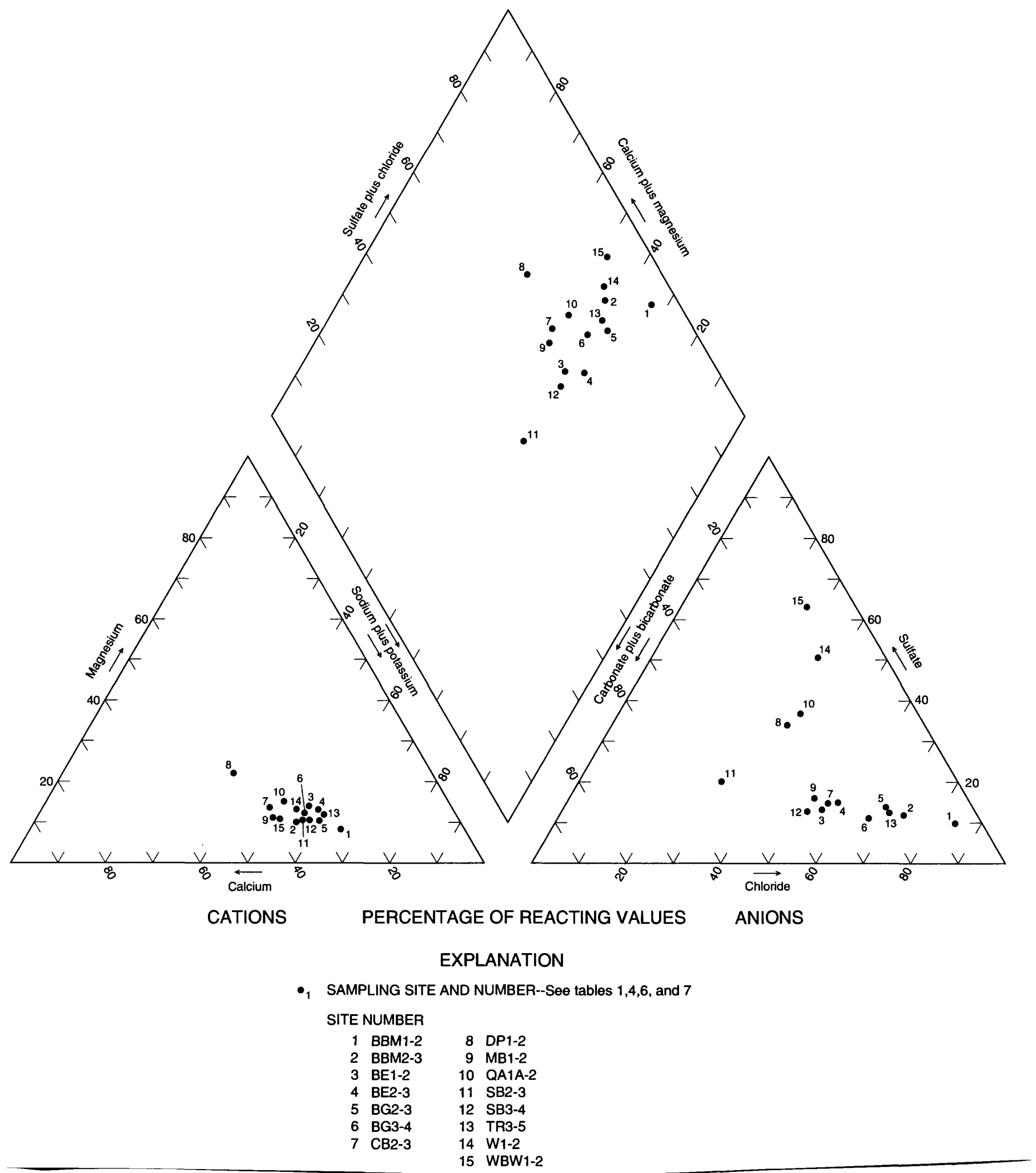

Figure 8. Composition of water from selected wetland streams, central and eastern Massachusetts, 1988-89. 

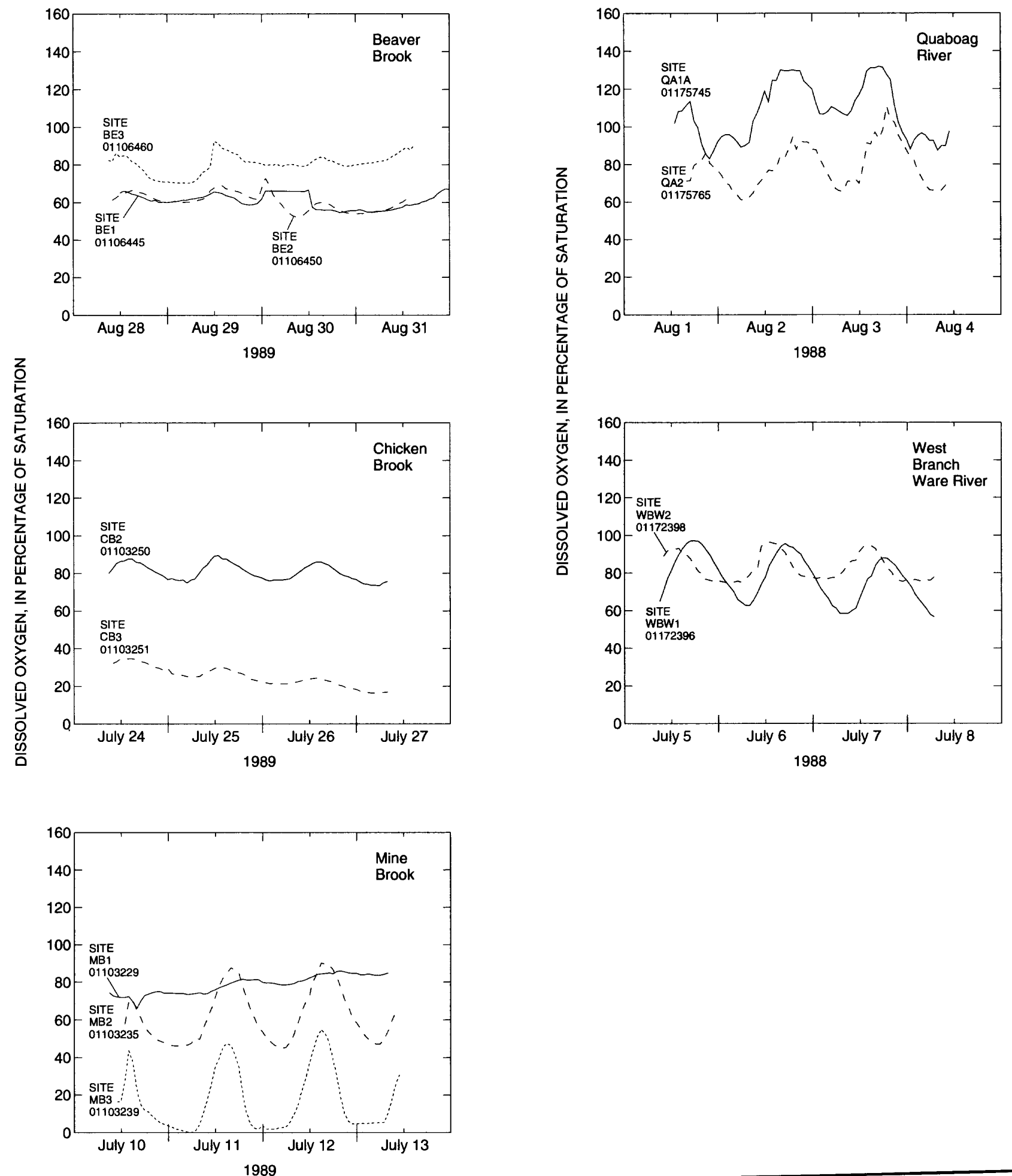

Figure 9. Percentage of saturation of dissolved oxygen for selected sampling sites, central and eastern Massachusetts, 1988-89. 
Table 5. Summary of water-quality data from selected wetland streams, central and eastern Massachusetts, 1988-89

[Fifteen samples were collected for each constituent or property, except chemical and biochemical oxygen demand, for which 14 samples were collected. All constituents are given in milligram per liter unless otherwise noted. Type of sampling site: $U$, upstream; D, downstream. $\mu \mathrm{S} / \mathrm{cm}$, microsiemen per centimeter at $25^{\circ} \mathrm{C} ; \mu \mathrm{g} / \mathrm{L}$, microgram per liter; ${ }^{\circ} \mathrm{C}$, degree Celsius; NTU, nephelometric-turbidity unit; Pt-Co units, platinum cobalt scale units]

\begin{tabular}{|c|c|c|c|c|c|c|}
\hline Constituent or property & $\begin{array}{l}\text { Type of } \\
\text { sampling } \\
\text { site }\end{array}$ & Minimum & Maximum & Median & Mean & $\begin{array}{l}\text { Standard } \\
\text { deviation }\end{array}$ \\
\hline \multirow[t]{2}{*}{ Specific conductance $(\mu \mathrm{S} / \mathrm{cm})$} & $\mathrm{U}$ & 42 & 641 & 157 & 192 & 146 \\
\hline & $\mathrm{D}$ & 42 & 301 & 175 & 179 & 80 \\
\hline \multirow[t]{2}{*}{$\mathrm{pH}$ (standard units) } & $\mathrm{U}$ & 6.1 & 7.5 & 6.6 & 6.7 & .39 \\
\hline & D & 6.2 & 7.3 & 6.5 & 6.6 & .33 \\
\hline \multirow[t]{2}{*}{ Temperature $\left({ }^{\circ} \mathrm{C}\right)$} & $\mathrm{U}$ & 13.0 & 24.5 & 17.5 & 19.5 & 3.6 \\
\hline & D & 14.0 & 26.0 & 20.0 & 20.0 & 3.7 \\
\hline \multirow[t]{2}{*}{ Color (Pt-Co units) } & $\mathrm{U}$ & 35 & 200 & 100 & 92 & 48 \\
\hline & D & 45 & 170 & 80 & 93 & 43 \\
\hline \multirow[t]{2}{*}{ Turbidity (NTU) } & $\mathbf{U}$ & .8 & 2.0 & 1.5 & 1.5 & 1.3 \\
\hline & D & 1.1 & 3.1 & 1.8 & 1.9 & .61 \\
\hline \multirow[t]{2}{*}{ Oxygen, dissolved } & $\mathrm{U}$ & .4 & 8.8 & 6.1 & 5.9 & 2.4 \\
\hline & $\mathrm{D}$ & .4 & 8.9 & 6.0 & 5.0 & 2.8 \\
\hline \multirow[t]{2}{*}{ Oxygen demand, chemical } & $\mathrm{U}$ & 16 & 86 & 39 & 42 & 19 \\
\hline & D & 18 & 83 & 39 & 42 & 15 \\
\hline \multirow[t]{2}{*}{ Oxygen demand, biochemical } & $\mathrm{U}$ & .9 & 6.0 & 3.2 & 3.3 & 1.5 \\
\hline & D & 1.8 & 5.1 & 2.9 & 3.3 & 1.1 \\
\hline \multirow[t]{2}{*}{ Calcium, dissolved } & $\mathrm{U}$ & 2.8 & 29 & 8.8 & 11 & 6.7 \\
\hline & $\mathrm{D}$ & 2.8 & 18 & 9.9 & 9.9 & 4.5 \\
\hline \multirow[t]{2}{*}{ Magnesium, dissolved (Pt-Co units) } & $\mathrm{U}$ & .53 & 5.2 & 2.2 & 2.2 & 1.1 \\
\hline & D & .45 & 3.1 & 2.3 & 2.2 & .8 \\
\hline \multirow[t]{2}{*}{ Sodium, dissolved. } & $\mathrm{U}$ & 4.0 & 84 & 17 & 21 & 19 \\
\hline & D & 4.1 & 32 & 19 & 19 & 9.1 \\
\hline \multirow[t]{2}{*}{ Potassium, dissolved } & $\mathrm{U}$ & .5 & 3.7 & 1.4 & 1.7 & 1.0 \\
\hline & D & .6 & 3.7 & 1.6 & 1.7 & .86 \\
\hline \multirow[t]{2}{*}{ Alkalinity (as $\mathrm{CaCO}_{3}$ ) } & $\mathrm{U}$ & 4 & 30 & 18 & 18 & 7.4 \\
\hline & D & 4 & 34 & 19 & 19 & 8.7 \\
\hline \multirow[t]{2}{*}{ Sulfate, dissolved } & $\mathrm{U}$ & 6 & 33 & 10 & 13 & 7.0 \\
\hline & D & 7 & 20 & 10 & 12 & 4.2 \\
\hline \multirow[t]{2}{*}{ Chloride, dissolved } & $\mathrm{U}$ & 6.2 & 180 & 22 & 34 & 44 \\
\hline & D & 4.8 & 68 & 27 & 27 & 18 \\
\hline \multirow[t]{2}{*}{ Nitrogen, nitrite, total (as N) } & $\mathrm{U}$ & .01 & .01 & .01 & .01 & 0 \\
\hline & $\mathrm{D}$ & .01 & .03 & .01 & .01 & .01 \\
\hline \multirow[t]{2}{*}{ Nitrogen, nitrite, dissolved (as $\mathbf{N}$ ) } & $\mathrm{U}$ & .01 & .01 & .01 & .01 & 0 \\
\hline & D & .01 & .03 & .01 & .01 & .01 \\
\hline
\end{tabular}


Table 5. Summary of water-quality data from selected wetland streams, central and eastern Massachusetts, 1988-89--Continued

\begin{tabular}{|c|c|c|c|c|c|c|}
\hline Constituent or property & $\begin{array}{c}\text { Type of } \\
\text { sampling } \\
\text { site }\end{array}$ & Minimum & Maximum & Median & Mean & $\begin{array}{l}\text { Standard } \\
\text { deviation }\end{array}$ \\
\hline \multirow[t]{2}{*}{ Nitrogen, nitrite plus nitrate, total (as N) } & $\mathrm{U}$ & 0.1 & 0.9 & 0.3 & 0.32 & 0.3 \\
\hline & D & .1 & 1.1 & .2 & .25 & .3 \\
\hline \multirow{2}{*}{$\begin{array}{l}\text { Nitrogen, nitrite plus nitrate, dissolved } \\
\quad \text { (as N) }\end{array}$} & $\mathrm{U}$ & .1 & .85 & .21 & .29 & .24 \\
\hline & $\mathrm{D}$ & .1 & 1.0 & .14 & .24 & .23 \\
\hline \multirow[t]{2}{*}{ Nitrogen, ammonia, total (as N) } & $\mathrm{U}$ & .01 & .15 & .05 & .06 & .04 \\
\hline & D & .01 & .18 & .04 & .06 & .04 \\
\hline \multirow[t]{2}{*}{ Nitrogen, ammonia, dissolved (as N) } & $\mathrm{U}$ & .01 & .11 & .04 & .05 & .03 \\
\hline & D & .01 & .17 & .05 & .06 & -.04 \\
\hline \multirow{2}{*}{$\begin{array}{l}\text { Nitrogen, ammonia plus organic, total } \\
\quad \text { (as N) }\end{array}$} & $\mathrm{U}$ & .3 & 2.1 & .8 & .77 & .49 \\
\hline & D & .4 & 2.1 & .8 & .9 & .45 \\
\hline \multirow{2}{*}{$\begin{array}{l}\text { Nitrogen, ammonia plus organic, } \\
\text { dissolved (as } \mathrm{N} \text { ) }\end{array}$} & $\mathrm{U}$ & .2 & .6 & .1 & .1 & .3 \\
\hline & D & .2 & 1.4 & .7 & .7 & .3 \\
\hline \multirow[t]{2}{*}{ Nitrogen, organic, total (as N) } & $\mathbf{U}$ & .22 & 2.1 & .71 & .72 & .48 \\
\hline & D & .36 & 2.1 & .72 & .85 & .46 \\
\hline \multirow[t]{2}{*}{ Nitrogen, organic, dissolved (as N) } & $\mathbf{U}$ & .11 & 1.5 & .46 & .55 & .35 \\
\hline & D & .19 & 1.3 & .66 & .64 & .32 \\
\hline \multirow{2}{*}{$\begin{array}{l}\text { Phosphorus, hydrolyzable plus } \\
\text { orthophosphate, total (as P) }\end{array}$} & U & .01 & .08 & .03 & .03 & .02 \\
\hline & D & .01 & .18 & .03 & .05 & .04 \\
\hline \multirow{2}{*}{$\begin{array}{l}\text { Phosphorus, hydrolyzable plus } \\
\text { orthophosphate, dissolved (as P) }\end{array}$} & $U$ & .01 & .03 & .01 & .02 & .01 \\
\hline & D & .01 & .13 & .02 & .03 & .03 \\
\hline \multirow[t]{2}{*}{ Phosphorus, organic, total (as P) } & $\mathbf{U}$ & .01 & .04 & .02 & .02 & .01 \\
\hline & D & .01 & .27 & .03 & .05 & .07 \\
\hline \multirow[t]{2}{*}{ Phosphorus, organic, dissolved (as P) } & $\mathbf{U}$ & .01 & .03 & .01 & .02 & .01 \\
\hline & D & .01 & .13 & .01 & .02 & .03 \\
\hline \multirow[t]{2}{*}{ Iron, dissolved $(\mu \mathrm{g} / \mathrm{L})$} & $\mathrm{U}$ & 70 & 930 & 460 & 515 & 262 \\
\hline & D & 150 & 1,500 & 750 & 748 & 392 \\
\hline \multirow[t]{2}{*}{ Carbon, organic, total (as C) } & $\mathrm{U}$ & .2 & 1.8 & .3 & .56 & .47 \\
\hline & D & .2 & 2.8 & .5 & .67 & .66 \\
\hline \multirow[t]{2}{*}{ Carbon, organic, dissolved (as C) } & $\mathrm{U}$ & 3.7 & 19 & 9.3 & 10 & 4.6 \\
\hline & D & 5.5 & 19 & 9.6 & 10 & 3.8 \\
\hline \multirow[t]{2}{*}{ Chlorophyll- $a$ (estimated) $(\mu \mathrm{g} / \mathrm{L})$} & $\mathrm{U}$ & .1 & 23 & .6 & 4.1 & 4.1 \\
\hline & D & .1 & 19 & .9 & 3.8 & 3.8 \\
\hline \multirow[t]{2}{*}{ Chlorophyll- $b$ (estimated) $(\mu \mathrm{g} / \mathrm{L})$} & $U$ & .1 & 3.5 & .1 & .4 & 7.6 \\
\hline & D & .1 & 3.1 & .1 & .4 & 6.0 \\
\hline \multirow[t]{2}{*}{ Sediment, suspended } & $\mathbf{U}$ & 1 & 22 & 3 & 5.4 & 6.3 \\
\hline & $\mathrm{D}$ & 1 & 19 & 5 & 5.8 & 4.3 \\
\hline
\end{tabular}


Concentrations of nitrogen species in the sampled wetland streams exhibit a wide range of values; dissolved nitrite plus nitrate as nitrogen ranged from 0.10 to $1.0 \mathrm{mg} / \mathrm{L}$, dissolved ammonia-nitrogen ranged from 0.01 to $0.17 \mathrm{mg} / \mathrm{L}$, and dissolved organic nitrogen ranged from 0.11 to $1.5 \mathrm{mg} / \mathrm{L}$ (table 5). Nitrate concentrations exceeding EPA national primary drinking-water standards of $10 \mathrm{mg} / \mathrm{L}$ were not detected (U.S. Environmental Protection Agency, 1994). The most common forms of nitrogen in stream water are nitrate, nitrite, ammonium, and organic nitrogen. Organic nitrogen is nitrogen that is included within proteins, amino acids, and other molecules formed by plants and animals.

Ammonification is the principal source of ammonium in aquatic systems in the absence of sewage-treatment plants. During ammonification, organic compounds containing nitrogen are broken down by bacteria into ammonia, which ionizes in water to become ammonium.

Ammonium exerts a high oxygen demand and is toxic to aquatic organisms. If oxygen is available, ammonium is converted by bacteria to nitrite, which is in turn quickly oxidized into nitrate. This process is called nitrification. The reverse of this process, called denitrification, generally occurs in streambed and wetland sediments in the absence of free oxygen. During denitrification, bacteria use nitrate as an electron acceptor in place of oxygen, resulting in the reduction of nitrate to nitrous oxide or nitrogen gas.

In acidic wetlands and streams organic substances known as humic and fulvic acids give the water a characteristic tea color. In the selected wetland streams, $\mathrm{pH}$ ranged from 6.1 to 7.5 , and the median $\mathrm{pH}$ values were 6.6 and 6.5 for upstream and downstream sites, respectively (table 5). Color ranged from 35 to $200 \mathrm{Pt}$-Co units in the selected wetland streams, and the median color levels were 100 and 80 platinum-cobalt (Pt-Co) units for upstream and downstream sites, respectively. DOC compounds include soluble carbohydrates and amino acids leached from decomposing organic material. DOC in the sampled wetland streams ranged from 3.7 to $19 \mathrm{mg} / \mathrm{L}$. Median DOC concentrations were 9.3 and $9.6 \mathrm{mg} / \mathrm{L}$ in upstream and downstream sampling sites, respectively. The low slopes and low stream velocities in wetland reaches create depositional environments that accumulate organic material. Organic matter produced by wetland vegetation, such as emergent macrophytes, tends to decompose in the water column at or near the site of production (Wetzel and Ward, 1992). Other organic matter may be transported into the wetland reach from upstream sources. This organic material exists in many forms, such as large particulate matter in the form of branches and vegetative debris and small particulate matter in the form of leaf litter, detritus, or colloidal material. Much of the organic matter present in streams has been in the water for some time, and is refractory in nature (decomposes slowly). However, the cumulative effect of large amounts of slowly decomposing organic material can exert substantial SOD.

The relative changes in water quality were plotted to test for consistent changes in water quality between the wetland reaches. Depending on the direction of change in the constituent throughout the reach, a plus $(+)$, minus (-), or zero (0) was plotted (tables 6 and 7 ). Constituents that increased throughout the primary reaches include the following (numbers in parentheses give the percentage of the reaches that increased for that constituent): discharge (87 percent), specific conductance (60 percent), temperature (67 percent), turbidity (73 percent), DO (53 percent), sodium (73 percent), dissolved potassium ( 53 percent), dissolved sulfate ( 53 percent), total ammonia plus organic nitrogen ( 60 percent), dissolved ammonia (60 percent), total orthophosphorus (53 percent), iron (67 percent), chlorophyll- $a$ (53 percent), and suspended sediment (67 percent). Decreases were measured in the primary reaches for DOC (53 percent). For the subordinate reaches, increases were measured in ammonia as nitrogen (50 percent).

Boxplots were constructed to display water quality at upstream and downstream boundaries of the stream reaches and to graph the differences between concentrations of constituents entering and leaving the wetland reaches. The nonparametric sign test and Wilcoxon signed-rank test were applied to test for significant differences between the upstream and downstream data. Few significant differences were detected at a $p$ value of less than 0.05 . Examples are given in figure 10 for (1) constituents that did not exhibit significant differences over the wetland reaches (specific conductance, $\mathrm{pH}$, color, sulfate, chloride, ammonium, and DOC), (2) constituents for which data indicate that the effect of the wetland was to increase or decrease the variability of the constituent (instantaneous DO, COD, total ammonia plus organic nitrogen, total hydrolizable plus orthophosphorus), and (3) constituents for which the data suggest a slight change may occur over the wetland reach (turbidity, BOD, iron, suspended sediment), but for which statistical tests using the nonparametric sign test and Wilcoxon signed-rank test did not indicate a significant difference at a $p$ value of less than 0.05 . 


1.5 times the interquartile range. Lower whisker end is minus 1.5 times the interquartile range.

Figure 10. Effects of wetland reaches on stream-water quality for selected properties and constituents, central and eastern Massachusetts, 1988-89. 
Table 6. Relative changes in water quality throughout primary wetland-stream reaches, central and

[N, data not available; + , increase throughout reach; - , decrease throughout reach; 0 , no change throughout reach]

\begin{tabular}{|c|c|c|c|c|c|c|c|c|c|}
\hline $\begin{array}{l}\text { Stream name } \\
\text { (river basin name) } \\
\text { and site No. }\end{array}$ & Discharge & $\begin{array}{l}\text { Specific } \\
\text { conduc- } \\
\text { tance }\end{array}$ & $\mathrm{pH}$ & $\begin{array}{l}\text { Temper- } \\
\text { ature }\end{array}$ & Color & Turbidity & $\begin{array}{l}\text { Oxygen, } \\
\text { dissolved }\end{array}$ & $\begin{array}{l}\text { Oxygen } \\
\text { demand, } \\
\text { chemical }\end{array}$ & $\begin{array}{l}\text { Oxygen } \\
\text { demand, Calcium } \\
\text { biochemical }\end{array}$ \\
\hline
\end{tabular}

$$
\text { Central Massachusetts (fig. 2) }
$$

Quaboag River

(Ware)

QA1A-2

Ware River

(Chicopee)

Wl-2

West Branch

Ware River (Ware)

WBW1-2

0

East-Central Massachusetts (fig. 3)

Beaver Brook

(Merrimack)

BBM1-2

BBM2-3

$\begin{array}{lllll}+ & - & - & + \\ + & - & - & + & +\end{array}$

Stony Brook

(Merrimack)

SB2-3

SB3-4

$+$

$+$

$\begin{array}{lllll}- & - & + & + & - \\ + & 0 & - & - & + \\ \text { Southeastern Massachusetts (fig. 5) }\end{array}$

Beaver Brook

(Taunton)

BE1-2

BE2-3

$\begin{array}{ll}+ & + \\ + & +\end{array}$

Bungay River

(Ten Mile)

BG2-3

BG3-4

Chicken Brook

(Charles)

CB2-3

Dopping Brook

(Charles)

DPl-2

Mine Brook

(Charles)

MB1-2

Town River

(Taunton)

$\begin{array}{lrrrrrrrrrr}\begin{array}{c}\text { TR3-5 } \\ \text { Total number of }+\end{array} & + & + & + & + & - & + & + & - & + \\ \text { Total number of }- & 2 & 9 & 7 & 10 & 7 & 11 & 8 & 5 & 7 \\ \text { Total number of } 0 & 1 & 5 & 7 & 4 & 7 & 2 & 7 & 7 & 5 \\ \end{array}$


eastern Massachusetts, 1988-89

\begin{tabular}{|c|c|c|c|c|c|c|}
\hline $\begin{array}{c}\text { Stream name } \\
\text { (river basin name) } \\
\text { and site No. }\end{array}$ & $\begin{array}{c}\text { Magnesium, } \\
\text { dissolved }\end{array}$ & $\begin{array}{l}\text { Sodium, } \\
\text { dissolved }\end{array}$ & $\begin{array}{c}\text { Potassium, } \\
\text { dissolved }\end{array}$ & Alkalinity & $\begin{array}{l}\text { Sulfate, } \\
\text { dissolved }\end{array}$ & $\begin{array}{l}\text { Chloride, } \\
\text { dissolved }\end{array}$ \\
\hline
\end{tabular}

Central Massachusetts (fig. 2)

Quaboag River

(Ware)

QA1A-2

Ware River

(Chicopee)

W1-2

West Branch

Ware River (Ware)

WBW 1-2

\begin{tabular}{l} 
WBW1-2 \\
\hline Beaver Brook \\
(Merrimack)
\end{tabular}

BBM1-2

BBM2-3

Stony Brook

(Merrimack)

SB2-3

SB3-4

$\begin{array}{ll}0 & + \\ + & +\end{array}$

$+$

$+\quad 0$

0

East-Central Massachusetts (fig. 3)

Beaver Brook

(Taunton)

BE1-2

BE2-3

$\begin{array}{ll}- & - \\ - & -\end{array}$

$\begin{array}{ll}- & - \\ - & 0\end{array}$

$\overline{0}$

+
+

$+$

$-$

$\overline{0}$

Bungay River

(Ten Mile)

BG2-3

BG3-4

$\begin{array}{lll}+ & + & + \\ + & - & +\end{array}$

+
+

$\begin{array}{ll}0 & + \\ 0 & -\end{array}$

$\begin{array}{ll}+ & + \\ - & +\end{array}$

Southeastern Massachusetts (fig. 5)

Chicken Brook

(Charles)

CB2-3

Dopping Brook

(Charles)

DP1-2

Mine Brook

(Charles)

MB1-2

Town River

(Taunton)

$$
\text { TR3-5 }
$$

Total number of +

Total number of -

Total number of 0

$\begin{array}{ll}0 & + \\ + & +\end{array}$

+
+

+
+

$-$

+
+

$\begin{array}{ll}+ & + \\ + & -\end{array}$

$\begin{array}{ll}- & -\end{array}$

0
0

0

$-$

$+$

$-$

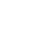

-

0

$+$


Table 6. Relative changes in water quality throughout primary wetland-stream reaches in central and

\begin{tabular}{|c|c|c|c|c|c|c|c|c|c|}
\hline \multirow{2}{*}{$\begin{array}{l}\text { Stream name } \\
\text { (river basin name) } \\
\text { and site No. }\end{array}$} & \multicolumn{2}{|c|}{ Nitrogen, nitrite } & \multicolumn{2}{|c|}{$\begin{array}{l}\text { Nitrogen, nitrite } \\
\text { plus nitrate }\end{array}$} & \multicolumn{2}{|c|}{$\begin{array}{l}\text { Nitrogen, } \\
\text { ammonia }\end{array}$} & \multicolumn{2}{|c|}{$\begin{array}{l}\text { Nitrogen, ammonia } \\
\text { plus organic }\end{array}$} & \multirow{2}{*}{$\begin{array}{l}\text { Phos- } \\
\text { phorus, } \\
\text { orthophos- } \\
\text { phate, total }\end{array}$} \\
\hline & Total & Dissolved & Total & Dissolved & Total & Dissolved & Total & Dissolved & \\
\hline \multicolumn{10}{|c|}{ Central Massachusetts (fig. 2) } \\
\hline $\begin{array}{l}\text { Quaboag River } \\
\text { (Ware) } \\
\text { QAlA-2 }\end{array}$ & 0 & 0 & 0 & 0 & 0 & - & + & 0 & + \\
\hline $\begin{array}{c}\text { Ware River } \\
\text { (Chicopee) } \\
\text { Wl-2 }\end{array}$ & 0 & 0 & 0 & 0 & + & + & 0 & + & 0 \\
\hline $\begin{array}{l}\text { West Branch } \\
\text { Ware River (Ware) } \\
\text { WBW1-2 }\end{array}$ & 0 & 0 & 0 & 0 & + & 0 & t & + & \\
\hline \multicolumn{10}{|c|}{ East-Central Massachusetts (fig. 3) } \\
\hline $\begin{array}{c}\text { Beaver Brook } \\
\text { (Merrimack) } \\
\text { BBM1-2 } \\
\text { BBM2-3 }\end{array}$ & $\begin{array}{l}0 \\
0\end{array}$ & $\begin{array}{l}0 \\
0\end{array}$ & $\overline{0}$ & $\overline{0}$ & $\overline{0}$ & $\bar{t}$ & $\bar{t}$ & $\overline{+}$ & $\begin{array}{l}0 \\
+\end{array}$ \\
\hline $\begin{array}{l}\text { Stony Brook } \\
\text { (Merrimack) }\end{array}$ & & & & & & & & & \\
\hline $\begin{array}{l}\text { SB2-3 } \\
\text { SB3-4 }\end{array}$ & $\begin{array}{l}0 \\
0\end{array}$ & $\begin{array}{l}0 \\
+\end{array}$ & $\begin{array}{l}+ \\
+\end{array}$ & $\begin{array}{l}+ \\
+\end{array}$ & $\begin{array}{l}+ \\
+\end{array}$ & $\begin{array}{l}+ \\
+\end{array}$ & $\begin{array}{l}0 \\
0\end{array}$ & $\overline{0}$ & $\begin{array}{l}0 \\
+\end{array}$ \\
\hline \multicolumn{10}{|c|}{ Southeastern Massachusetts (fig. 5) } \\
\hline $\begin{array}{c}\text { Beaver Brook } \\
\text { (Taunton) } \\
\text { BE1-2 } \\
\text { BE2-3 }\end{array}$ & $\begin{array}{l}0 \\
+\end{array}$ & $\begin{array}{l}0 \\
+\end{array}$ & $\begin{array}{l}+ \\
+\end{array}$ & $\begin{array}{l}+ \\
+\end{array}$ & $\begin{array}{l}0 \\
+\end{array}$ & $\begin{array}{l}0 \\
+\end{array}$ & + & $\begin{array}{l}0 \\
+\end{array}$ & + \\
\hline $\begin{array}{c}\text { Bungay River } \\
\text { (Ten Mile) } \\
\text { BG2-3 } \\
\text { BG3-4 }\end{array}$ & $\begin{array}{l}0 \\
0\end{array}$ & $\begin{array}{l}0 \\
0\end{array}$ & - & - & - & $\bar{t}$ & $\begin{array}{l}+ \\
+\end{array}$ & $\begin{array}{l}+ \\
+\end{array}$ & $\stackrel{+}{0}$ \\
\hline $\begin{array}{l}\text { Chicken Brook } \\
\text { (Charles) } \\
\text { CB2-3 }\end{array}$ & + & + & - & - & + & + & + & + & + \\
\hline $\begin{array}{l}\text { Dopping Brook } \\
\text { (Charles) } \\
\text { DP1-2 }\end{array}$ & 0 & 0 & - & - & - & - & - & 0 & 0 \\
\hline $\begin{array}{l}\text { Mine Brook } \\
\text { (Charles) } \\
\text { MBl-2 }\end{array}$ & 0 & 0 & 0 & - & - & - & + & + & - \\
\hline $\begin{array}{l}\text { Town River } \\
\text { (Taunton) } \\
\text { TR3-5 }\end{array}$ & 0 & 0 & 0 & - & - & - & + & + & + \\
\hline Total number of + & 2 & 3 & 4 & 4 & 7 & 7 & 9 & 9 & 8 \\
\hline Total number of - & 0 & 0 & 5 & 4 & 5 & 6 & 3 & 2 & 1 \\
\hline Total number of 0 & 13 & 12 & 6 & 7 & 3 & 2 & 3 & 4 & 6 \\
\hline
\end{tabular}




\begin{tabular}{|c|c|c|c|c|c|c|c|c|c|}
\hline \multirow[t]{2}{*}{$\begin{array}{c}\text { Stream name } \\
\text { (river basin name) } \\
\text { and site No. }\end{array}$} & \multirow{2}{*}{$\begin{array}{l}\text { Phosphorus, } \\
\text { orthophos- } \\
\text { phate, } \\
\text { dissolved }\end{array}$} & \multicolumn{2}{|c|}{$\begin{array}{l}\text { Phosphorus, } \\
\text { hydrolizable plus } \\
\text { orthophosphate }\end{array}$} & \multirow[t]{2}{*}{$\begin{array}{l}\text { Iron, } \\
\text { dissolved }\end{array}$} & \multicolumn{2}{|c|}{ Carbon, organic } & \multirow[t]{2}{*}{$\begin{array}{l}\text { Chloro- } \\
\text { phyll- } a\end{array}$} & \multirow[t]{2}{*}{$\begin{array}{l}\text { Chloro- } \\
\text { phyll- } b\end{array}$} & \multirow[t]{2}{*}{$\begin{array}{c}\text { Suspended } \\
\text { sediment }\end{array}$} \\
\hline & & Total & Dissolved & & Total & Dissolved & & & \\
\hline \multicolumn{10}{|c|}{ Central Massachusetts (fig. 2) } \\
\hline $\begin{array}{l}\text { Quaboag River } \\
\text { (Ware) }\end{array}$ & & & & & & & & & \\
\hline & 0 & 0 & + & + & - & + & - & - & + \\
\hline $\begin{array}{l}\text { Ware River } \\
\text { (Chicopee) } \\
\text { W1-2 }\end{array}$ & 0 & 0 & 0 & + & + & + & + & 0 & + \\
\hline $\begin{array}{l}\text { West Branch } \\
\text { Ware River (Ware) } \\
\text { WBW1-2 }\end{array}$ & - & 0 & 0 & + & - & - & - & - & + \\
\hline \multicolumn{10}{|c|}{ East-Central Massachusetts (fig. 3) } \\
\hline $\begin{array}{c}\text { Beaver Brook } \\
\text { (Merrimack) } \\
\text { BBM1-2 } \\
\text { BBM2-3 }\end{array}$ & $\begin{array}{l}0 \\
0\end{array}$ & $\begin{array}{l}+ \\
+\end{array}$ & $\overline{+}$ & $\overline{+}+$ & $\begin{array}{l}+ \\
+\end{array}$ & $\begin{array}{l}+ \\
-\end{array}$ & $\begin{array}{l}+ \\
+\end{array}$ & $\begin{array}{l}+ \\
+\end{array}$ & $\begin{array}{l}+ \\
+\end{array}$ \\
\hline $\begin{array}{c}\text { Stony Brook } \\
\text { (Merrimack) } \\
\text { SB2-3 } \\
\text { SB3-4 }\end{array}$ & $\begin{array}{l}0 \\
0\end{array}$ & $\stackrel{+}{0}$ & $\begin{array}{l}0 \\
0\end{array}$ & $\begin{array}{l}+ \\
0\end{array}$ & - & $\begin{array}{l}- \\
-\end{array}$ & - & $\overline{+}$ & $\overline{-}$ \\
\hline \multicolumn{10}{|c|}{ Southeastern Massachusetts (fig. 5) } \\
\hline $\begin{array}{l}\text { Beaver Brook } \\
\text { (Taunton) } \\
\text { BE1-2 } \\
\text { BE2-3 }\end{array}$ & + & $\begin{array}{l}0 \\
+\end{array}$ & $\bar{t}$ & $\bar{t}$ & $\begin{array}{l}0 \\
0\end{array}$ & $\overline{0}$ & $\stackrel{+}{-}$ & $\begin{array}{l}0 \\
0\end{array}$ & $\begin{array}{l}+ \\
+\end{array}$ \\
\hline $\begin{array}{c}\text { Bungay River } \\
\text { (Ten Mile) } \\
\text { BG2-3 } \\
\text { BG3-4 }\end{array}$ & $\begin{array}{l}+ \\
0\end{array}$ & $\begin{array}{l}+ \\
0\end{array}$ & $\begin{array}{l}+ \\
0\end{array}$ & $\begin{array}{l}+ \\
-\end{array}$ & $\begin{array}{l}0 \\
0\end{array}$ & $\begin{array}{l}+ \\
+\end{array}$ & - & $\begin{array}{l}0 \\
0\end{array}$ & $\begin{array}{l}+ \\
+\end{array}$ \\
\hline $\begin{array}{l}\text { Chicken Brook } \\
\text { (Charles) } \\
\text { CB2-3 }\end{array}$ & + & + & + & + & + & + & + & 0 & + \\
\hline $\begin{array}{l}\text { Dopping Brook } \\
\text { (Charles) } \\
\text { DP1-2 }\end{array}$ & - & 0 & - & + & + & - & + & + & - \\
\hline $\begin{array}{l}\text { Mine Brook } \\
\text { (Charles) } \\
\text { MB1-2 }\end{array}$ & 0 & - & 0 & - & 0 & - & + & 0 & 0 \\
\hline $\begin{array}{l}\text { Town River } \\
\text { (Taunton) } \\
\text { TR3-5 }\end{array}$ & + & + & + & + & + & - & + & + & - \\
\hline Total number of + & 4 & 7 & 6 & 10 & 6 & 6 & 8 & 5 & 10 \\
\hline Total number of - & 3 & 1 & 3 & 4 & 4 & 8 & 7 & 3 & 4 \\
\hline Total number of 0 & 8 & 7 & 6 & 1 & 5 & 1 & 0 & 7 & 1 \\
\hline
\end{tabular}


Table 7. Relative changes in water quality throughout subordinate wetland-stream reaches, central and eastern Massachusetts, 1973-81

[Data from Socolow (1994). N, data not available, + , increase throughout reach; - , decrease throughout reach; 0, no change throughout reach]

\begin{tabular}{|c|c|c|c|c|c|c|c|c|c|c|c|}
\hline $\begin{array}{c}\text { Stream name } \\
\text { (river basin } \\
\text { name) } \\
\text { and site No. }\end{array}$ & $\begin{array}{l}\text { Date of } \\
\text { sample }\end{array}$ & $\mathrm{pH}$ & Color & Turbidity & $\begin{array}{l}\text { Oxygen } \\
\text { demand, } \\
\text { biochem- } \\
\text { ical }\end{array}$ & $\begin{array}{l}\text { Alka- } \\
\text { linity }\end{array}$ & $\begin{array}{l}\text { Nitro- } \\
\text { gen, } \\
\text { nitrite }\end{array}$ & $\begin{array}{l}\text { Nitrogen, } \\
\text { ammonia }\end{array}$ & $\begin{array}{l}\text { Nitrogen, } \\
\text { total, } \\
\text { kjeldahl }\end{array}$ & $\begin{array}{c}\text { Phos- } \\
\text { phorus, } \\
\text { total }\end{array}$ & $\begin{array}{c}\text { Sus- } \\
\text { pended } \\
\text { sedi- } \\
\text { ment }\end{array}$ \\
\hline
\end{tabular}

\section{Central Massachusetts (fig. 2)}

Quaboag River

(Ware)

QA2-3

$7-16-74+\mathrm{N}$

$\begin{array}{llll}\mathrm{N} & + & 0 \\ \text { East-Central Massachusetts (fig. 3) }\end{array}$

Assabet River

(Concord)

AS 1-2

6-04-74 $0 \quad \mathrm{~N}$

$\mathrm{N}$

9-17-74 $+\mathrm{N}$

$\mathrm{N}$

$\begin{array}{ll}- & 0 \\ - & 0\end{array}$

Stony Brook

(Merrimack)

SB2-3

$\begin{array}{llll}6-25-74 & + & \mathrm{N} & \mathrm{N} \\ 8-27-74 & 0 & \mathrm{~N} & \mathrm{~N} \\ 6-25-74 & + & \mathrm{N} & \mathrm{N} \\ 8-27-74 & + & \mathrm{N} & \mathrm{N}\end{array}$

$\begin{array}{ll}\mathrm{N} & + \\ \mathrm{N} & - \\ \mathrm{N} & +\end{array}$

Sudbury River

(Concord)

$$
\text { SU4-5 }
$$

\begin{tabular}{llllll}
$7-10-73$ & - & $\mathrm{N}$ & $\mathrm{N}$ & 0 & + \\
$8 / 28 / 73$ & - & $\mathrm{N}$ & $\mathrm{N}$ & - & - \\
$6 / 11 / 79$ & - & $\mathrm{N}$ & + & - & $\mathrm{N}$ \\
$8 / 13 / 79$ & + & $\mathrm{N}$ & + & - & $\mathrm{N}$ \\
\hline
\end{tabular}

Northeastern Massachusetts (fig. 4)

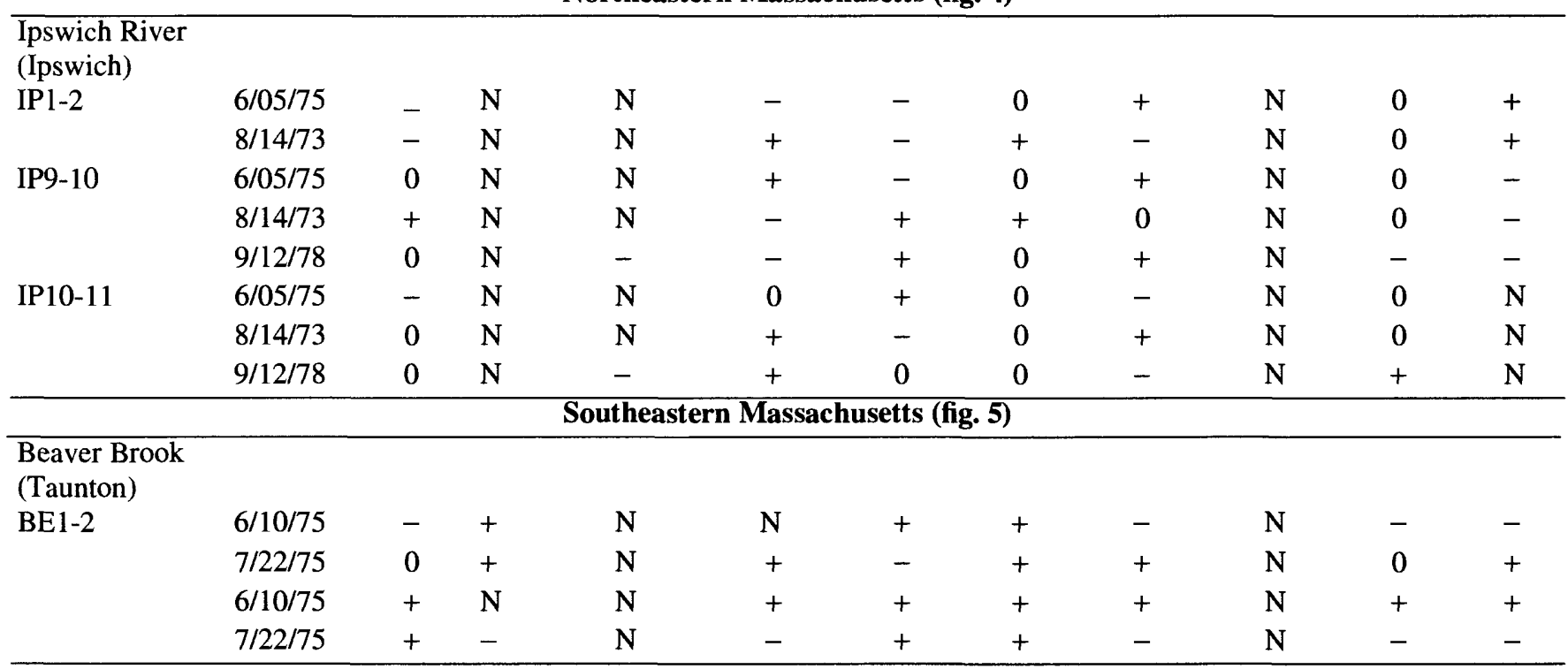


Table 7. Relative changes in water quality throughout subordinate wetland-stream reaches in central and eastern Massachusetts, 1973-81--Continued

\begin{tabular}{|c|c|c|c|c|c|c|c|c|c|c|c|}
\hline $\begin{array}{c}\text { Stream name } \\
\text { (river basin } \\
\text { name) } \\
\text { and site No. }\end{array}$ & $\begin{array}{l}\text { Date of } \\
\text { sample }\end{array}$ & $\mathrm{pH}$ & Color & Turbidity & $\begin{array}{l}\text { Oxygen } \\
\text { demand, } \\
\text { biochem- } \\
\text { ical }\end{array}$ & $\begin{array}{l}\text { Alka- } \\
\text { linity }\end{array}$ & $\begin{array}{l}\text { Nitro- } \\
\text { gen, } \\
\text { nitrite }\end{array}$ & $\begin{array}{l}\text { Nitrogen, } \\
\text { ammonia }\end{array}$ & $\begin{array}{l}\text { Nitrogen, } \\
\text { total, } \\
\text { kjeldahl }\end{array}$ & $\begin{array}{c}\text { Phos- } \\
\text { phorus, } \\
\text { total }\end{array}$ & $\begin{array}{c}\text { Sus- } \\
\text { pended } \\
\text { sedi- } \\
\text { ment }\end{array}$ \\
\hline \multicolumn{12}{|c|}{ Southeastern Massachusetts (fig. 5)--Continued } \\
\hline $\begin{array}{l}\text { Charles River } \\
\text { (Charles) } \\
\text { CH5-6 }\end{array}$ & $6 / 23 / 81$ & 0 & $N$ & $\mathrm{~N}$ & + & - & - & - & - & - & - \\
\hline $\begin{array}{l}\text { Chicken Brook } \\
\text { (Charles) }\end{array}$ & $6123 / 81$ & & N & N &  & + & 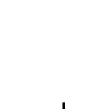 & + & 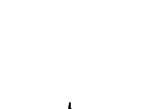 & 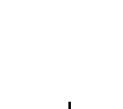 & 1 \\
\hline $\begin{array}{l}\text { Dopping Brook } \\
\text { (Charles) } \\
\text { DP1-2 }\end{array}$ & $6 / 23 / 81$ & + & $\mathrm{N}$ & $\mathrm{N}$ & - & + & - & - & - & - & - \\
\hline \multicolumn{12}{|l|}{$\begin{array}{l}\text { Town River } \\
\text { (Taunton) }\end{array}$} \\
\hline & $7 / 22 / 75$ & + & $\mathrm{N}$ & $\mathrm{N}$ & + & + & - & - & $\mathrm{N}$ & + & + \\
\hline & $6 / 10 / 75$ & + & - & $\mathrm{N}$ & + & - & + & - & $\mathbf{N}$ & - & - \\
\hline & $7 / 22 / 75$ & + & + & $\mathrm{N}$ & + & + & - & + & $\mathrm{N}$ & + & + \\
\hline Total number of & + & 13 & 3 & 2 & 14 & 14 & 13 & 15 & 1 & 11 & 13 \\
\hline Total number of & & 9 & 2 & 2 & 13 & 10 & 8 & 12 & 3 & 9 & 13 \\
\hline Total number of & & 8 & 0 & 0 & 2 & 4 & 9 & 3 & 1 & 10 & 0 \\
\hline
\end{tabular}

Wetlands may increase or decrease the loads of certain constituents in the stream. Differences in load were calculated using the following equation:

Difference in load $=(C d \times Q d)-(C u \times Q u)$, where:

$C d$ is concentration at downstream sampling site;

$Q d$ is discharge at downstream sampling site;

$C u$ is concentration at upstream sampling site; and

$Q u$ is discharge at upstream sampling site.

When boxplots were constructed for loads instead of concentrations, the loads for most constituents increased from upstream to downstream for most reaches. However, because the discharges also increased for these reaches, the changes in load are most likely to be caused by the increases in discharge instead of increases in the concentrations of constituents. Using the nonparametric sign test and Wilcoxon signed-rank test, significant differences at $p$ values of less than 0.01 were detected between constituent loads at upstream and downstream sampling sites for calcium, magnesium, potassium, total ammonia as nitrogen, ammonia plus organic nitrogen, total hydrolizable plus orthophosphorus, and iron.

The effect of stream and wetland characteristics were analyzed by grouping stream and wetland characteristics by relative differences and constructing boxplots for water quality at upstream and downstream sites and for differences in the water-quality constituents over the wetland reach. Few significant differences were detected. Boxplots that display constituents of interest for which data indicate slight differences are included in figure 11. Some caution should be used in interpreting these boxplots because of the small size of the data set. 
A.


B.

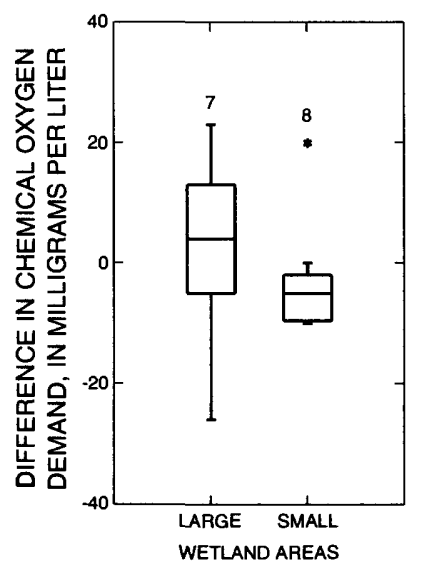

C.

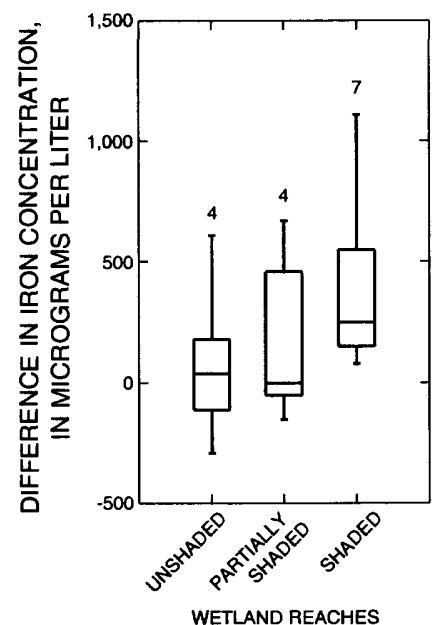

WETLAND REACHES

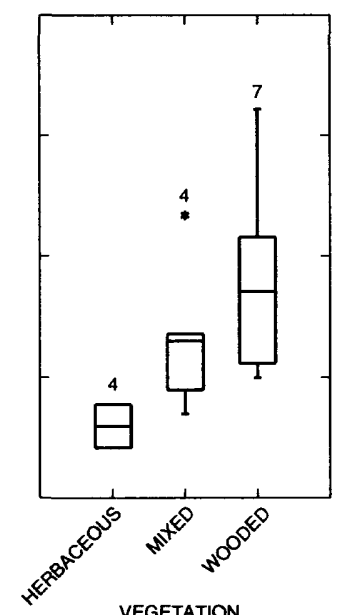

VEGETATION

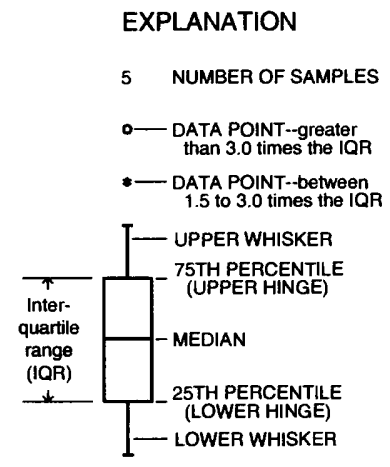

Upper whisker end is defined as the largest data
point less than or equal to the upper quartile plus 1.5 times the interquartile range. Lower whisker

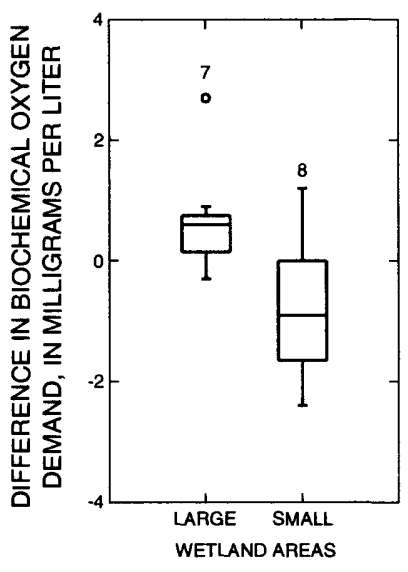

Figure 11. Effects of wetland characteristics on the water quality of selected wetland streams, central and eastern Massachusetts, 1988-89. (A) Differences in discharge, temperature, and chemical oxygen demand throughout wetland reaches in early, mid-, and late summer. $(B)$ Differences in concentration of chemical oxygen demand and biochemical oxygen demand over wetland reaches that have large and small wetland areas. (C) Differences in iron concentration in open, partially shaded, and shaded wetland reaches and in wetlands covered predominantly by herbaceous, mixed, or woody vegetation. 
Several relations can be observed in the boxplots. Discharge and temperature appear to have greater variability in early summer than in late summer. Low flows and high temperatures would result in less than optimal DO concentrations. Temperature has a direct relation with the rate of growth and decomposition of algae and bacteria. Consequently, COD and BOD in the selected streams were higher in late summer than in early summer and also appear to be higher in reaches that have large wetland areas. Large amounts of organic matter that originate or accumulate in these reaches provide a large sink for DO upon their decay. Although SOD was not measured during this investigation, high temperatures in late summer also would result in high concentrations of SOD. At the same time, decreased stream velocities associated with low flows would increase the effect of SOD on a given volume of water by increasing the time of travel through the wetland reaches. In addition to an increase in oxygen demands in late summer, DO also is proportionately less available in the stream to meet oxygen demands because of lower flows, reduced reaeration caused by decreased stream surface areas and reduced turbulence associated with low flows, and because temperature has an inverse relation with DO saturation. Although production and respiration conditions may balance in early summer, respiration dominates in late summer as light availability decreases and temperatures remain high. Oxygen demands that do not affect the stream much at other times of the year, such as the discharge of ground water that has low concentrations of DO or high concentrations of reduced chemical constituents, may have relatively greater effects during periods of low flows. Wetland streams likely have less capacity to absorb additional oxygen demands during late summer than during other periods.

\section{Limitations of the Data}

Limitations of the data analyzed for this report may have prevented detection of relations between physical characteristics and water quality in wetland reaches. Initially, an objective of this study was to develop equations for expressing relations between stream-water quality and physical, hydrological, and climatological characteristics of riparian wetlands (N.C. Suurballe, U.S. Geological Survey, written commun., 1989). In addition to collection of water-quality data by the USGS, the study was to make use of the large data base of water-quality data collected by the MDEP. Data collected by the MDEP were initially collected for the purposes of monitoring and reporting the stream-water quality in the Commonwealth. Consequently, most data were collected in reaches of streams suspected to have water-quality problems caused by point sources of pollution such as sewage-treatment plants.

Additional limitations of the data were caused by the timing and frequency of sampling. The initial study design required sampling of a large number of reaches. Consequently, many of the sites sampled by the MDEP also were sampled by the USGS. Although the MDEP data base is quite extensive, measurements of many water-quality constituents or physical and biological conditions that would have been useful to meet the objectives of this report are not present in the data base because the initial MDEP data-collection program was designed for a different purpose. For example, one of the primary ways that wetlands affect stream-water quality is through contact time with organic material in the wetland. Time-of-travel data are necessary for calculation of productivity, respiration, and community metabolism with the use of a computer program developed by Stephens and Jennings (1976) and are important variables in the Streeter-Phelps equation (Mills and others; Thomann and Mueller, 1987) and many other waterquality models. Although time of travel can be approximated by the velocities from discharge measurements, this practice is discouraged (Mills and other, 1985). The MDEP data base also did not have data on barometric pressure concurrent with DO sampling. These data are necessary for calculation of percentage of saturation of DO. Many water-quality constituents cycle on a seasonal basis in response to biologic cycles and different flow conditions. Many of the data collected by the MDEP and USGS cannot be directly compared between streams because the streams were sampled at different times of the year. Similarly, the response of an individual wetland reach to different flow conditions and seasonal cycles cannot be discerned because each reach was only sampled for a 2- to 4-day period once per year, and antecedent conditions are unknown.

The MDEP monitoring program and the study design for this investigation (which was implemented with the collaboration of the USGS and MDEP) required that a large number of wetland reaches be sampled. Consequently, ease of access was a consideration, and sampling sites were located at road crossings to save time and expense. However, road crossings seldom coincide with boundaries of natural features such as wetlands. Because most of the sampling sites were within wetland 
complexes and not upstream and downstream of the wetland proper and because paired reaches in upland areas were not sampled as a control, the changes in water quality that are observed between the upstream and downstream sampling sites may not be attributed solely to the presence of wetlands.

Three methods of analysis that were initially identified as appropriate for interpretation of the effects of wetlands on stream-water quality were unsuccessful when applied to the MDEP and USGS data. These methods were Odum 2-station analysis (Owens, 1974; Stephens and Jennings, 1976) for estimation of daytime productivity, night respiration, and net community metabolism; the Streeter-Phelps equation (Mills and others, 1985; Thomann and Mueller, 1987) for prediction of downstream DO conditions using upstream DO data; and the use of multiple regression to develop equations for prediction of DO and nutrient concentrations from easily measured physical and hydrological characteristics of riparian wetlands.

In an effort to improve understanding of the sources and sinks of DO, available data initially were used in a computer program developed by Stephens and Jennings (1976) that uses Odum two-station analysis to estimate daytime production, night respiration, and net-community metabolism. This program requires inputs of hourly DO, a diffusion constant (reaeration), salinity, mean depth, time of sunrise and sunset, barometric pressure, mean velocity, surface area, and traveltime. Data for diffusion constant, mean depth, mean velocity, surface area, and traveltime were unavailable for this study. Consequently, diffusion constants were estimated using mean depths and an empirical equation for determining reaeration rate from the work of Parker and DeSimone (1992). Values for mean depth, mean velocity, and traveltime were estimated from discharge measurements made at upstream and downstream ends of the reaches. Results from the computer program were inconclusive, most likely because of the error associated with estimation of variables. Mean depths and velocities calculated from discharge measurements at the upstream and downstream ends of a wetland reach represent the means for water moving through the reach and do not account for standing water (water in storage) in the wetland reach. Consequently, estimated mean depths and traveltimes likely underestimated actual depths and traveltimes in the wetland reaches, and estimated mean velocities likely overestimated velocities in the wetland reaches. Long traveltimes that increase the time of contact between water and organic materials in wetland reaches may be the principal means by which wetlands affect water quality. Careful measurement of these variables concurrent with water-quality sampling may prove beneficial for future investigations.

In an effort to predict water quality downstream of wetland reaches, oxygen deficits determined from DO data collected downstream of wetland reaches were compared to oxygen deficits predicted by the StreeterPhelps equation (Mills and others, 1985; Thomann and Mueller, 1987). The Streeter-Phelps equation requires inputs of upstream oxygen deficits, BOD, reaeration coefficients, BOD decay rates, reach length, and average velocity. Values for mean depth and velocity were estimated from discharge measurements made at upstream and downstream ends of the reaches. Reaeration coefficients were estimated using mean depths and an empirical equation for determining reaeration rates from the work of Parker and DeSimone (1992); BOD decay rates were estimated using published values from Bowie and others (1985). Results from application of the StreeterPhelps equation were inconclusive, most likely owing to error associated with estimation of variables and because of violations of assumptions in the equation when applied to wetland reaches. Although modified versions of the Streeter-Phelps equation (Mills and others, 1985; Thomann and Mueller, 1987) can account for carbonaecous BOD and nitrogenous BOD, these equations do not account for the addition of BOD throughout the wetland reach, bacterial respiration, reduced reaeration due to surfactants (Parker and DeSimone, 1992), benthic photosynthesis, SOD created by organic detritus in the wetland reach, discharge of anoxic ground water containing reduced compounds such as iron $\left(\mathrm{Fe}^{2+}\right)$, manganese $\left(\mathrm{Mn}^{2+}\right)$, sulfide $\left(\mathrm{HS}^{1-}\right)$, or ammonium $\left(\mathrm{NH}_{4}^{+}\right)$, and photochemical reactions involving iron-humicmatter complexes (Miles and Brezonik, 1981). The MDEP previously attempted to use the Streeter-Phelps equation for the prediction of DO in wetland streams and determined that it poorly predicts DO conditions (Arthur Screpetis, Massachusetts Department of Environmental Protection, oral commun., 1993). 
An exhaustive effort was made to use multiple regression for development of predictive equations (R.S. Socolow, U.S. Geological Survey, written commun., 1992). Analysis of data were completed on the full set of MDEP and USGS data in Socolow (1994). No relations between DO and nutrient concentrations and hydrological, biological, and physical characteristics of wetland streams were detected using multiple regression analysis (R.S. Socolow, U.S. Geological Survey, written commun., 1992). The lack of relation could have been caused by numerous factors, including: (1) data were collected and compared across several growing seasons, whereas many constituents cycle seasonally, (2) critical data, such as traveltime, were not collected, and (3) insufficient samples were collected. Because of differing sample times and the nature of the variability of DO concentrations through a daily cycle, multiple regression may have been more successful if productivity or productivity/respiration (P/R) ratios could have been used as the independent variable, if those data were available, instead of DO concentrations. Multiple regression was not used after stream reaches were screened for this report owing to the small size of the remaining data set.

\section{Need for Further Study}

Although conditions in many Massachusetts streams have improved since the 1960's and early 1970's, low DO and high nutrient concentrations remain a problem in some wetland streams. A carefully designed data-collection program is needed to successfully evaluate DO and nutrient behavior in wetland reaches. Components of the data-collection program would include careful site selection, proper timing and intensity of sampling throughout the year, and additional water-quality data required for DO and nutrient modeling.

The selection of sampling sites is critical to the study design of any future investigation of the effects of wetlands on stream-water quality. In most cases, logistics and personnel would limit intensive investigation to three or four streams. The study described in this report included a large number of reaches, limiting the frequency of sampling in any one reach. Study design also limited most sampling to sites adjacent to road crossings. However, road crossings seldom coincide with the boundaries of natural features such as wetlands.

Sampling locations would be most appropriate if established where streams flow into and out of wetland areas. Reaches in upland areas also would need to be sampled to serve as controls. Ideally, upland reaches just upstream of wetland reaches could be selected so that the effects of the wetland and upland reaches on the same parcel of water could be directly compared using Lagrangian sampling. If several paired reaches are selected along the same stream system, comparisons could be made between the water quality of wetlands on low-order and high-order streams and the water quality in the nonwetland reaches.

In addition to sampling upstream and downstream boundaries of a study reach, data collection along a reach would confirm where water-quality changes occur within the stream reach and whether these changes were sudden or gradual. This sampling also may provide information about where in the stream processes such as nitrification or denitrification occur. Additional sampling adds expense, but often it is the only way to control variability and reduce uncertainty. Quantification of identified inflows, such as ground water, tributaries, or storm sewers, would aid in pinpointing sources of water-quality changes. Similarly, if lakes or impoundments are between the sampling sites, then the stream would need to be sampled upstream and downstream of these features so that their effects can be clearly discerned.

Temporal aspects of sampling also are critical to study design. Because of the large number of streams sampled, the current study sampled each stream only once and made comparisons among data that spanned different seasons, years, and decades. The uncertainty inherent in this approach is that it does not allow for detection of the effects of wetlands during storms nor for the detection of seasonal effects, climatic cycles, or changes in land use. If the samples are collected monthly or at more frequent intervals throughout a year, data fluctuations in response to hydrologic and biologic cycles may be discerned.

Extensive water-quality data are required for investigation of the effects of wetlands on stream-water quality. Data would include major ions, physical properties, nutrients, and organic carbon. Investigation of DO requires continuous water-quality monitoring of $\mathrm{DO}$ and temperature. Data for barometric pressure and time-oftravel data also are necessary. Differences in sources and sinks of DO can be evaluated using calculations of production, respiration, and community metabolism. Two commonly used measurements of community metabolism are $\mathrm{P} / \mathrm{R}$ and net-daily metabolism (NDM). The $\mathrm{P} / \mathrm{R}$ indicates the proportion of respiration that could be supported by ongoing autotrophic production, whereas the NDM indicates the absolute amount of respiration that is being supported by sources other than ongoing autotrophic production, such as from allochthonous 
organic material or upstream autotrophic production (Meyer and Edwards, 1990). Several methods are available to determine primary productivity, community respiration, and stream metabolism in a stream reach, including open-stream oxygen change or carbon dioxide change, oxygen change in chambers, $\mathrm{C}-14$ techniques (Bott and others, 1978), and diurnal curve analysis (Erdmann, 1979a, 1979b). Direct measurement of SOD could provide important information on DO sinks that may otherwise be unavailable.

Information about the wetland and upland reaches is useful to have before comparing data. Knowledge of local conditions, such as canopy shading, stream depths, substrate materials, nature of wetland vegetation, presence of point sources of pollution, geology, soils, and local land use, is invaluable to understanding water quality. Much of this information is only available through onsite investigation.

Although the Streeter-Phelps equation (Thomann and Mueller, 1987) is useful for determining the downstream effects of point sources of waste discharges in wetland reaches characterized by changing channel geometries and diffuse sources of nutrients and organic material, the Streeter-Phelps equation may be an oversimplification. There are several more advanced waterquality models that may be appropriate to use in an investigation of the effects of wetlands on stream-water quality. A numerical model that is widely used for wasteload allocations is QUAL2E (Brown and Barnwell, 1987). QUAL2E can simulate 15 water-quality constituents, including temperature, DO, BOD, nitrite, nitrate, ammonia, organic nitrogen, organic phosphorus, dissolved phosphorus, coliforms, algae as chlorophyll- $a$, and conservative and nonconservative constituents (Brown and Barnwell, 1987). QUAL2E can be operated as a dynamic model to study the effects of diurnal variations in meteorological data on water quality or to study diurnal DO variations due to algal growth and respiration. Another model that can simulate the transport and transformation of conventional and toxic pollutants, as well as eutrophication-DO kinetics is WASP (Water Quality Analysis Simulation Program) (DiToro and others, 1983). WASP can simulate three organic parameters (nitrogen, phosphorus, and carbon), six inorganic constituents (DO, chloride, silica, nitrite plus nitrate nitrogen, ammonia as nitrogen, and orthophosphate phosphorus) and two biological compartments (phytoplankton and zooplankton) (Thomann and Mueller, 1987). Application of these models requires that study and data-collection activities be designed specifically to meet the data requirements of the models.
Multivariate statistical techniques, such as principle component analysis (PCA), are appropriate for examining the relation among several quantitative variables simultaneously (SAS Institute, Inc., 1990). PCA could be used to relate physical characteristics of basins, streams, and wetlands (independent variables) to stream-water quality (dependent variables). For example, Whittier and others (1988) used PCA to show relations between ecoregions in Oregon and water quality and physical habitats of streams, and Johnston and others (1990) successfully applied PCA to investigate the cumulative effect of wetlands on stream-water quality and quantity in Minnesota. Like the application of water-quality models, however, such an approach would require that study and data-collection activities be designed specifically to meet the data requirements of the method of analysis.

\section{SUMMARY}

The purposes of this report are to describe basin, stream, and wetland characteristics for selected wetlands of central and eastern Massachusetts; to describe the concentrations of $\mathrm{DO}$, nutrients, and other water-quality characteristics; to describe limitations of the data for determining relations among basin, stream, and wetland characteristics and water quality of wetland streams; and to identify additional data and information needed to understand processes that affect water quality of wetland streams.

Data used in this investigation were selected from Socolow (1994). Data in Socolow (1994) were collected by the MDEP from 1962 through 1988, and by the USGS from 1988 through 1989. The data include a wide range of water-quality and stream and wetland characteristics. Wetland reaches described by Socolow (1994) were evaluated to restrict the data set to natural systemsstream reaches where water quality was not affected by point-source discharges-and to eliminate reaches that may have been affected by other than wetland factors, such as lakes or tributaries. Data from 22 wetland reaches on 15 streams in central and eastern Massachusetts were selected for analysis. Water-quality data were analyzed by construction of boxplots for selected water-quality constituents and for basin, stream, and wetland characteristics. Nonparametric statistical techniques were used to check for significant differences between concentrations and loads from upstream and downstream sampling sites. 
Stream nutrient and DO conditions were quite variable in the selected wetland-stream reaches. For 15 wetland streams, constituents that increased in more than 65 percent of the reaches included discharge, specific conductance, temperature, turbidity, sodium, dissolved and total ammonia plus organic nitrogen, and iron. Easily measured characteristics of wetland streams were not reliable indicators of water quality for the existing data set. A literature review indicates that wetlands can have a wide variety of effects on stream-water quality and that an intensive data-collection program would be necessary to identify these effects. In this study, the lack of consistent changes in water quality between the upstream and downstream sampling sites suggests that the existing data for the selected wetland reaches cannot be used to reliably determine the effect of wetlands on stream-water quality.

A carefully designed data-collection program is needed for the successful evaluation of dissolved oxygen and nutrients in wetland reaches. The data-collection program needs to be designed specifically to meet the data requirements of the method of analysis. Components of the data-collection program would include careful site selection, proper timing and intensity of sampling throughout the year, and additional water-quality data for dissolved oxygen and nutrient modeling.

\section{REFERENCES CITED}

Beck K.C., Reuter, J.H., and Perdue, E.M., 1974, Organic and inorganic geochemistry of some coastal plain rivers of the southeastern United States: Geochimica et Cosmochimica Acta, v. 38, p. 341-364.

Bott, T.L., Brock, J.T., Cushing, C.E., Gregory, S.V., King, D., and Petersen, R.C., 1978, A comparison of methods for measuring primary productivity and community respiration in streams: Hydrobiologia, v. 60 , no. 1 , p. 3-12.

Bowie, G.L., Mills, W.B., Porcella, D.B., Campbell, C.L., Pagenkopf, J.R., Rupp, G.L., Johnson, K.M., Chan, P.W.H., Gherini, S.A., and Chamberlin, C.E., 1985, Rates, constants, and kinetics formulations in surface water quality modeling: U.S. Environmental Protection Agency, EPA/600/3-85/040, 455 p.

Brinson, M.B., 1988, Strategies for assessing the cumulative effects of wetland alteration on water quality: Environmental Management, v. 12, p. 655-662.

Britton, L.J., and Greeson, P.E., eds., 1989, Methods for collection and analysis of aquatic biological and microbiological samples: U.S. Geological Survey Techniques of Water-Resources Investigations, book 5 , chap. A4, $363 \mathrm{p}$.
Brown, L.C., and Barnwell, T.O., Jr., 1987, The enhanced stream water quality models QUAL2E and QUAL2EUNCAS-Documentation and user manual: U.S. Environmental Protection Agency, EPA/600/3-87/007, $189 \mathrm{p}$.

Cowardin, L.M., Carter, Virginia, Golet, F.C., and LaRoe, E.T., 1979, Classification of wetlands and deepwater habitats of the United States: U.S. Fish and Wildlife Service Report FWS/OBS-79/31, 131 p.

DiToro, D.M., Fitzpatrick, J.J., Thomann, R.V., 1983, Documentation for water quality analysis simulation program (WASP) and model verification program (MVP): U.S. Environmental Protection Agency, EPA-600/3-81-044, 145 p.

Edwards, R.W., 1968, Plants as oxygenators in rivers: Water Research, v. 2, p. 243-248.

Elder, J.F., 1985, Nitrogen and phosphorus speciation and flux in a large Florida river wetland system: Water Resources Research, v. 21, p. 724-732.

1988, Factors affecting wetland retention of nutrients, metals, and organic materials, in Wetland hydrology, Proceedings of the National Wetlands Symposium, Chicago, Ill., Sept. 16-18, 1987: Berne, N.Y., Association of State Wetland Managers, p. 205-212.

Erdmann, J.B., 1979a, Systematic diurnal curve analysis: Journal Water Pollution Control Federation, v. 51, no. 1, p. 78-86.

1979b, Simplified diurnal curve analysis: American Society of Civil Engineers, $21 \mathrm{p}$.

Fishman, M.J., and Friedman, L.C., eds., 1985, Methods for determination of inorganic substances in water and fluvial sediments: U.S. Geological Survey Techniques of Water-Resources Investigations, book 3, chap. C2, 59 p.

Frimpter, M.H., 1988, Massachusetts ground-water quality, in National Water Summary 1986-Hydrologic events and ground-water quality: U.S. Geological Survey WaterSupply Paper 2325, p. 297-304.

Gadoury, R.A., and Wandle, S.W., 1986, Massachusetts surface-water resources, in National Water Summary 1985-Hydrologic events and surface-water resources: U.S. Geological Survey Water-Supply Paper 2300, p. 271-276.

Guy, H.P., and Norman, V.W., 1970, Field methods for measurement of fluvial sediment: U.S. Geological Survey Techniques of Water-Resources Investigations, book 3, chap. C2, $59 \mathrm{p}$.

Hampson, P.S., 1989, Dissolved-oxygen concentrations in a central Florida wetlands stream, in Wetlands-Concerns and successes: American Water Resources Association, p. 149-159.

Helsel, D.R., and Hirsch, R.M., 1992, Statistical methods in water resources: New York, Elsevier Science Pub. Co., Inc., $522 \mathrm{p}$. 
Hem, J.D., Demayo, Adrian, and Smith, R.A., 1990, Hydrogeochemistry of rivers and lakes, in Wolman, M.G., and Riggs, H.C., eds., Surface water hydrology: Boulder, Colo., Geological Society of America, The Geology of North America, v. O-1, chap. 9, p. 189-231.

Hemond, H.F., and Benoit, Janina, 1988, Cumulative impacts on water quality functions: Environmental Management, v. 12 , p. 639-653.

Hoskin, C.M., 1959, Studies of oxygen metabolism of streams of North Carolina: Port Aransas, Texas, Publications of the Institute of Marine Science, v. 6-8, p. 186-192.

Hynes, H.B.N., 1974, The biology of polluted waters: Toronto, University of Toronto Press, $202 \mathrm{p}$.

Johnston, C.J., Detenbeck, N.E., and Niemi, G.J., 1990, The cumulative effect of wetlands on stream-water quality and quantity-A landscape approach: Biogeochemistry, v. 10 , p. 105-141.

Jorgensen, Neil, 1977, A guide to New England's landscape: Chester, Conn., The Globe Pequot Press, 256 p.

Likens, G.E., Bormann, F.H., Pierce, R.S., Eaton, J.S., and Johnson, N.M., 1977, Biogeochemistry of a forested ecosystem: New York, Springer-Verlag, $146 \mathrm{p}$.

Madson, E. L., Morgan, M.D., and Good, R.E., 1986, Simultaneous photoreduction and microbial oxidation of iron in a stream in the New Jersey Pinelands: Limnology and Oceanography, v. 31 , no. 4, p. 832-838

Massachusetts Department of Environmental Protection, 1992, Commonwealth of Massachusetts Summary of water quality, 1992: North Grafton, Mass., Massachusetts Department of Environmental Protection, Division of Water Pollution Control, $96 \mathrm{p}$.

Meyer, J.L., and Edwards, R.T., 1990, Ecosystem metabolism and turnover of organic carbon along a blackwater river continuum: Ecology, v. 71, no. 2, p. 668-677.

Miles, C.J., and Brezonik, P.L., 1981, Oxygen consumption in humic-colored waters by a photochemical ferrous-ferric catalytic cycle: Environmental Science and Technology, v. 15 , no. 9 , p. 1089-1095.

Mills, W.B., Porcella, M.J., Ungs, M.L., Gherini, S.A., Summers, K.V., Mok, Lingfung, Rupp, G.L., Bowie, G.L., and Haith, D.A., 1985, Water quality assessmentA screening procedure for toxic and conventional pollutants in surface and ground water (revised 1985): U.S. Environmental Protection Agency, EPA/600/6-85/002a, $609 \mathrm{p}$.
Mitsch, W.J., and Gosselink, J.G., 1986, Wetlands: New York, Von Nostrand Reinhold, 88 p.

Motts, W.S., and O'Brien, A.L., 1981, Geology and hydrology of wetlands in Massachusetts: Amherst, University of Massachusetts, Water Resources Research Center, Publication No. 123, 147 p.

Mulholland, P.J., 1981, Organic carbon flow in a swamp, stream ecosystem: Ecological Monographs, v. 51, no. 3, p. 307-322.

Mulholland, P.J., and Kuenzler, E.J., 1979, Organic carbon export from upland and forested wetland watersheds: Limnology and Oceanography, v. 24, p. 969-966.

O'Brien, A.L., 1977, Hydrology of two small wetland basins in eastern Massachusetts: Water Resources Bulletin, v. 13 , no. 2 , p. $325-340$.

1980 , The role of ground water in stream discharges from two small wetland controlled basins in eastern Massachusetts: Ground Water, v. 18, no. 4, p. 359-365.

1988, Evaluating the cumulative effects of alteration on New England wetlands: Environmental Management, v. 12 , p. 627-636.

Owens, M., 1974, Measurements on non-isolated natural communities in running waters, in Vollenweider, R.A., ed., A manual on methods for measuring primary productivity in aquatic environments: Oxford, Blackwell Scientific, IBP Handbook No. 12, p. 111-119.

Parker, G.W., and DeSimone, L.A., 1992, Estimating reaeration coefficients for low-slope streams in Massachusetts and New York, 1985-88: U.S. Geological Survey Water-Resources Investigations Report 91-4188, $34 \mathrm{p}$.

Parker, G.W., and Suurballe, N.C., 1988, Differences in oxygen productivity rates and reaeration coefficients for wetland reaches of Natty Pond Brook, Massachusetts, in Wetland hydrology, Proceedings of the National Wetlands Symposium, Chicago, Ill., Sept., 16-18, 1987: Berne, N.Y., Association of State Wetland Managers, p. 205-212.

Peverly, J.H., 1982, Stream transport of nutrients through a wetland: Journal of Environmental Quality, v. 11, no. 1, p. 38-43.

1985, Element accumulation and release by macrophytes in a wetland stream: Journal of Environmental Quality, v. 14, no. 1, p. 137-143. 
Rantz, S.E., and others, 1982, Measurement and computation of streamflow: U.S. Geological Survey Water-Supply Paper 2175, $631 \mathrm{p}$.

Richardson, C.J., 1989, Freshwater wetlands-Transformers, filters, or sinks, in Freshwater wetlands and wildlife: U.S. Department of Energy, Symposium Series, no. 61, p. 25-46.

Rittmaster, R.L., and Shanley, J.B., 1994, Factors affecting water quality and net flux of solutes in two stream basins in the Quabbin Reservoir drainage basin, central Massachusetts, 1983-85: U.S. Geological Survey WaterResources Investigations Report 94-4003, 66 p.

Sammel, E.A., 1967, Water resources of the Parker and Rowley River Basins, Massachusetts: U.S. Geological Survey Hydrologic Investigations Atlas HA-247, 1 sheet, scale 1:24,000.

SAS Institute, Inc., 1990, SAS/STAT users guide, version 6, volume 2: Cary, N.C., SAS Institute Inc. 846 p.

Skougstad, M.W., Fishman, M.J., Friedman, L.C., Erdmann, D.E., and Duncan, S.S., eds., 1979, Methods for determination of inorganic substances in water and fluvial sediments: U.S. Geological Survey Techniques of Water-Resources Investigations, book 5, chap. A1, $626 \mathrm{p}$.

Socolow, R.S., 1994, Water-quality data for selected wetland streams in central and eastern Massachusetts: U.S.Geological Survey Open-File Report 93-482, 89 p.

Stephens, D.W., and Jennings, M.J., 1976, Determination of primary productivity and community metabolism in streams and lakes using diel oxygen measurements: Bay St. Louis, Miss., U.S.Geological Survey Computer Program Documentation, program no. J330, 100 p.

Suurballe, N.C., 1992, Effects of a wetland on quality of Natty Pond Brook, Massachusetts, 1985-86: U.S. Geological Survey Water-Resources Investigations Report 91-4144, $52 \mathrm{p}$.

Thomann, R.V., and Mueller, J.A., 1987, Principles of surface water quality modeling and control: New York, Harper and Row, $644 \mathrm{p}$.
Thyssen, Niels, Erlandsen, Mogens, Jeppesen, Eric, and Ursin, Christian, 1987, Reaeration of oxygen in shallow, macrophyte rich streams, I-Determination of the reaeration rate coefficient: Internationale Revue der Gesamten Hydrobiologie, v. 72, no. 4, p. 405-429.

Trombley, T.J., 1991, Quality of water from public-supply wells in Massachusetts, 1975-86: U.S. Geological Survey Water-Resources Investigations Report 91-4129, $63 \mathrm{p}$.

U.S. Environmental Protection Agency, 1994, National Primary Drinking Water Standards: Washington DC, Office of Water, EPA 810-F-94-001A, February 1994.

Wershaw, R.L., Fishman, M.J., Grabbe, R.R., and Lowe, L.E., eds., 1987, Methods for the determination of organic substances in water and fluvial sediments: U.S. Geological Survey Techniques of Water-Resources Investigations, book 5 , chap. A3, $80 \mathrm{p}$.

Wetzel, R.G., and Ward, A.K., 1992, Primary production, in Calow, Peter, and Petts, G.E., eds., The rivers handbook: Oxford, Blackwell Scientific Publications, p. 354-369.

Whigham, D.F., Chitterling, Carin, and Palmer, Brian, 1988, Impacts of freshwater wetlands on water quality $-\mathrm{a}$ landscape perspective: Environmental Management, v. 12 , p. 663-671.

Whittier, T.R., Hughes, R.M., and Larson, D.P., 1988, Correspondence between ecoregions and spatial patterns in stream ecosystems in Oregon: Canadian Journal of Fisheries and Aquatic Sciences, v. 45, no. 7, p. 1264-1278.

Winter, T.C., 1988, A conceptual framework f or assessing cumulative impacts on the hydrology of nontidal wetlands: Environmental Management, v. 12, p. 605-620.

Wood, W.W., 1976, Guidelines for collection and field analysis of ground-water samples for selected unstable constituents: U.S. Geological Survey Techniques of Water-Resources Investigations, book 1, chap. D2, 24 p. 